\title{
On the economic impact of droughts in Central Europe. The decade from 1531 to 1540 from the Polish perspective
}

Tomasz Związek ${ }^{1 *}$, Piotr Guzowski²*, Radosław Poniat ${ }^{2}$, Maciej T. Radomski ${ }^{3}$, Monika KozłowskaSzyc $^{2}$, Tomasz Panecki ${ }^{4}$, Sandra Słowińska ${ }^{1}$, Bogusława Kruczkowska ${ }^{5}$, Michał Targowski ${ }^{6}$, Dagmara 5 Adamska $^{7}$

${ }^{1}$ Stanisław Leszczycki Institute of Geography and Spatial Organization, Polish Academy of Sciences, Warsaw, 00-818, Poland ${ }^{2}$ Faculty of History and International Relations, University of Białystok, Białystok, 15-420, Poland

${ }^{3}$ Institute of Archaeology and Ethnology, Polish Academy of Sciences, Warsaw, 00-140, Poland

${ }^{4}$ Tadeusz Manteuffel Institute of History, Polish Academy of Sciences, Warsaw, 00-272, Poland

10 5epartment of Soil Science, Institute of Agriculture, Warsaw University of Life Sciences - SGGW, 02-776 Warsaw, Poland ${ }^{6}$ Faculty of History, Nicolaus Copernicus University, W. Bojarskiego 1, 87-100, Toruń, Poland

${ }^{7}$ Faculty of Historical and Pedagogical Sciences, History Department, Szewska 49, 50-139 Wrocław, Poland

Correspondence to: Tomasz Związek (tzwiazek@twarda.pan.pl)

* Both authors contributed equally.

15 Abstract. The period from around 1450 to 1550 in Europe is extremely interesting from the perspective of research on extreme weather events. It was a period of events that strongly influenced the societies and economies of the Old Continent. So far, the literature has been more focused on Western and Northern Europe, while as regards the region of Central Europe, the greatest attention was paid to the Czech Republic or Hungary. This article revolves around the Polish lands, which experienced their greatest economic boom in the 16th century. We consider whether and how the droughts of the decade from 1531 to 1540 might have affected the country's economic development. We analyze a number of written sources which are the product of the treasury apparatus of the time (tax registers, data from water customs, tax exemptions, inventories of land estates etc.), but also information on fluctuations in product prices in the most important cities in this part of Europe. The work not only provides a detailed account of economic data, but also attempts to reflect on the relevance of linking information on fires in urban centres in the period characterized by weather extremes.

\section{Introduction}

In the most recent two decades research done in the field of historical climatology has made a significant advance in our knowledge of how societies functioned in the past, and how they dealt with climate variability throughout the centuries (Ljungqvist et al., 2021). However, much still remains to be done. In this paper, we would like to focus on the one, very short, but also very important decade and discuss the economic effects of droughts in Early Modern Poland. A direct inspiration for this study can be found in the article published in 2020 in the "Climate of the Past" entitled Central Europe, 1531-1540 CE: The driest summer decade of the past five centuries? (Brázdil et al., 2020). As we see it, our study should possibly be treated 
https://doi.org/10.5194/cp-2021-157

Preprint. Discussion started: 29 November 2021

(c) Author(s) 2021. CC BY 4.0 License.

\section{(c) (i)}

as a comprehensive historical supplement of the abovementioned paper. By studying the Polish lands in the past, we would like to try to deeply understand the reactions of the economic system of the Early Modern state to extreme weather events. Also, in our paper we have focused on the Polish lands, which in the 16th century were becoming part of the global economic system and were undergoing a modernization process. Written sources from that period and context provided by recent Central European research, may, in our opinion, enrich the existing climatological discourse (Brázdil et al., 2013a; Brázdil et al., 2013b; Brázdil et al., 2018; Camenisch et al., 2016; Camenisch et al., 2020; Kiss, 2014, 2017, 2018, 2019; Kiss and Nikolić, 2015; Kiss and Pribyl, 2019; Huhtamaa and Helama, 2017).

Drought is a recurring extreme weather event and affects both ecosystems and various sectors of the economy. Therefore,

40 drought can be defined from different perspectives. Meteorological drought occurs when the atmospheric conditions result in the absence or reduction of precipitation. Atmospheric conditions that result in rainfall deficit depend on the geographic location and water resources; therefore, the understanding and scale of meteorological drought may differ from region to region. In turn, agricultural drought (or soil moisture drought) refers to a deficit of (mostly root zone) soil moisture. It is usually associated with meteorological drought, and this relationship is complex and dependent on many factors and determinants. The final effect of agricultural drought is a crop yield reduction. Hydrological drought is associated with the effects of periods of precipitation shortfalls on surface or subsurface water supply (i.e. streamflow, lake levels, groundwater). Socioeconomic drought is associated with the supply and demand of some economic goods with elements of all the abovementioned types of drought (Heim, 2002; Labędzki and Bąk, 2017; Wilhite and Glantz, 1985; Seneviratne et al., 2012).

Addressing the economic significance of droughts is important in the context of the current discussion on adaptation factors and methods with regard to changing climatic conditions (Degroot et al., 2021). Of particular relevance are the potential agricultural consequences associated with the occurrence of droughts. They can pose a serious threat to soil functions and productivity, especially in agricultural ecosystems (Liu et al., 2010; Geng et al., 2014). Soil moisture, despite climatic conditions, depends i.a. on soil organic matter (SOM) content, texture, porosity, relief and land use. Sandy soils, poor in organic matter, located on terrain elevations without access to groundwater, are particularly exposed to rapid drying. Soils devoid of vegetation are exposed to accelerated evaporation of the soil surface, leading to overdrying. If reduced, soil water content, a prerequisite for plant growth, limits the solubility and availability of nutrients for plants, lowers the biological and chemical activity of the soil and may contribute to disturbances in soil temperature regulation (He and Dijkstra, 2014; Wang et al., 2012; Mahajan et al., 2018; Siebielec et al., 2020; Al-Kayssi et al., 1990).

If the decade from 1531 to 1540 is placed in a broad context, it can be seen that several years $(1531,1534,1535,1538$ and

60 1540) can be distinguished for which dendrochronological data provide evidence of the occurrence of droughts in Central Europe (Cook et al., 2015). Similarly, data for eastern Europe (1531, 1532 and 1533) show that periods of severe droughts occurred mostly at the beginning of the studied decade (Cook et al., 2020). The researchers led by Rudolf Brázdil indicated that droughts occurring in the years 1534, 1536, 1538 and 1540 had a pan-European character (Brázdil et al., 2020). Nevertheless, the year 1540 should be treated separately; thus, according to a rich literature, it has an extreme character and 65 huge influence on the European societies and economy (Wetter and Pfister, 2013; Wetter et al., 2014; Büntgen et al., 2015; 
https://doi.org/10.5194/cp-2021-157

Preprint. Discussion started: 29 November 2021

(c) Author(s) 2021. CC BY 4.0 License.

(c) (i)

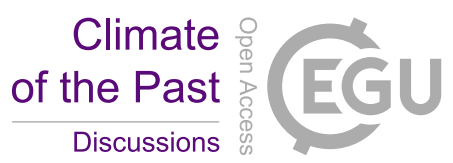

Pfister et al., 2015; Orth et al., 2016; Pfister, 2017, 2018; Nowosad and Oliński, 2020). On the other hand, looking more specifically at the Polish context of climatological research one can observe that in the 16th century the smallest number of droughts in the Polish lands were recorded, and their intensity was not substantial (Przybylak et al., 2020).

Nevertheless, it should be remembered that all the phenomena described here fall within what in Polish historiography is called

70 the "Polish Golden Age". In a broader sense, this concept can refer to the issues of art, culture, statehood, religious tolerance and even the significant development of philosophical thought. However, at this point we are especially interested in the economic factors. We also want to see how the Polish state got rich in exporting crops and forest products to Western Europe (Małowist, 2006). In this aspect, we assume that the Polish state has not been affected by any major crisis in the decade from 1531 to 1540 . The period from the end of the 15 th century to the middle of the 17 th century, which overlaps with the greatest

75 development of culture, philosophical thought, education and political activity, can therefore be regarded as a period of fundamental economic development.

\subsection{Data and methods}

We refer to data collected by the Polish economic historians, but also we use the archival materials related to the functioning of the Jagiellonian state and royal treasury apparatus. While selecting the final dataset, we tried to use as much information as

80 possible related to the decade from 1531 to 1540 . Written materials used in this study were selected on the basis of three factors:

a) their mass character, i.e. they record the course of economic processes, recurring and common, as well as everyday economic activity rather than the individual experience of, for example, the chronicle's author,

b) broad spatial coverage,

85 c) the homogeneity of the material, i.e. its standardized form resulting from its quantitative nature and a particular type of land ownership.

The historical data used in this research have been collected in a form that permits a quantitative analysis. An important element in the process of organizing the obtained information was to divide it into three time periods, which were classified as those relating to the period before, during and after the decade we are interested in (White et al., 2021). This approach resulted from

90 the desire to capture as broad a view as possible of the phenomena occurring in the economy at the time. We have carried out the main part of our work trying to look at the decade from 1531 to 1540 as a coherent epoch. However, we recognize that our observations may be heavily influenced by the climatic events of the 1540 mega-drought (see section 1.1)

We have used for our analysis the three oldest records of state tax revenues (tax summaries) that have been preserved up to now (Boroda, 2013; Boroda, 2016). They come from the years 1533, 1535 and 1543 (Archival Sources 1-3). For analytical

95 purposes we have compared only data from four lands (Latin: terrae) included in all three registers: Brześć Kujawski (terra Brestensis), Płock (terra Plocensis), Dobrzyń (terra Dobrinensis), and Sochaczew (terra Sochaczoviensis).

Additionally, in order to consider the relationship between climatic conditions and the spread of cities and towns fires we used the chancellery books of Polish kings (so-called Crown Metric) (Archival Sources 4; Wierzbowski, 1910, 1912, 1915, 1917, 
1919). These books consist of many tax exemptions granted by monarchs due to the occurrence of fire in a particular town or its part, which is particularly relevant in the context of observing the effects of an exceptional drought.

We consider cereals (mainly rye) to be the most reliable export commodity in the agricultural economy of that time. Therefore, we have analysed the data on harvests in ecclesiastical manors of the Cuyavia bishopric (Żytkowicz, 1962) and royal estates (Wawrzyńczyk, 1974), where we have focused in particular on the Malbork estates of Eastern Prussia in northern Poland (Szpak, 1971).

105 We have also used sets of historical prices from the largest Polish cities of the period like: Kraków, Gdańsk or Lviv (Pelc, 1935, 1937; Hoszowski, 1928). We have also analysed the average annual and quarterly prices of key agricultural products, i.e. various kinds of grain, as well as beer, hence the basic product of the processing sector connected with both agriculture and water management. Due to the large devaluation of money, the prices were converted into grams of silver in our analyses. An important supplement to the above data was the information on the grain exports from Baltic ports. We have taken into account both the production from Eastern Pomerania and that sent down the Vistula River from inland based on the lists of the water duty in Włocławek from the 16th century (Kutrzeba and Duda, 1915). Also Sundtoll data were used (Ellinger and Korst, 1906).

In addition to the above-mentioned sources recording the course of economic processes, the most popular early modern Polish agricultural handbooks were used in our text, showing the reflections of the contemporaries on the weather conditions affecting

115 farming.

\subsection{Methodology}

The historical data used in this research have been collected in a form that permits quantitative analysis. An important element in the process of organizing the obtained information was to divide it into three time periods, which were classified as those relating to the period before, during and after the decade in question (White et al., 2021). This approach resulted from the desire to capture as broad a view as possible of the phenomena occurring in the economy at the time. We have carried out the main part of our work trying to look at the decade from 1531 to 1540 as a coherent epoch. However, we recognize that our observations may be heavily influenced by the climatic events of the 1540 mega-drought.

The available source material did not allow us to analyze data from inventories related to the cultivation of perennial crops (e.g. vine bushes) as is the case in research in other parts of Central Europe (Chuine et al., 2004; Krieger et al., 2011; Labbé et

125 al., 2019). The sources that we used were related to the most important economic products of Poland at that time, i.e. various types of cereals, which formed the basis of the diet of people of all social groups, and were predominantly exported to Western Europe during the 16th century (Wyczański, 1985; Boroda, 2016). We hypothesized that intense weather- and climate-induced economic crises should have a significant impact on the macroeconomics of a given region. 


\section{Results and discussion}

130 The majority of our analysis is based on indicators related to the production, trade and exports of cereal products. These were the sigs that accounted for the economic strength of the country in the period under scrutiny. Cereals in Early Modern Poland should be divided into winter (rye, wheat, barley) and spring (oats, barley, buckwheat, rye, and wheat). Among them, winter rye was the leading crop, followed by spring oats, spring barley, and winter wheat. Spring rye and spring wheat played a secondary role in the economy. Their sowing was recommended by the authors of farming handbooks only if winter sowing failed (Gostomski, 1951; Rostafiński, 1891). The said authors wrote that the time of spring sowing was in March (very close to St. Bartholomew's Day - 12 March). In turn, the time of sowing rye and winter wheat fell between the end of August and the beginning of October (Gostomski, 1951; Piprek, 1954; Chomętowski, 1878; Rostafiński, 1891). Agricultural literature, however, does not provide precise dates for sowing rye and spring wheat.

There is much less information about the harvesting period, which was a direct result of the local conditions. According to the

140 recommendations in agricultural literature of the period the harvest of winter crops should end in August (Chomętowski, 1878). Winter barley ripened earliest (approx. 25 June), followed by winter rye (approx. 4 July). The authors reported that rye was harvested earlier than wheat (Piprek, 1954). On the other hand, the harvest of spring cereals began in the last days of August (Chomętowski, 1878; Rostafiński, 1891). Some of the writers pointed out that harvesting should be done in dry and sunny weather, but they also warned against harvesting during the rain (Gostomski, 1951; Rostafiński, 1891).

145 Manuring of the fields was also important in the cultivation of the cereals. Writers of the studied period treated manuring as a matter of fact and at the same time as a necessity, which is evidenced by numerous pieces of advice concerning methods of increasing the amount of manure (e.g. mixing the manure with rotten weeds or sheaves of old ploughing), ways of its storage, time and technique of soil manuring. What is more, they were well aware of the existence of relations not only between manuring and improvement of soil quality, but they also made the sowing of particular plant species dependent on soil types

150 (Gostomski, 1951; Piprek, 1954; Legatowicz, 1823). However, there are indications suggesting that the world of farming in the Middle Ages and Early Modern period suffered from a chronic shortage of manure (Newman and Harvey, 1997). Hence, cereals requiring less organic material were probably grown on Polish soils (as a result of the shortage of manure and the condition of the soil). Nevertheless, it is extremely interesting that the authors of agrarian textbooks more often paid attention to excessive soil moisture than to drought (Piprek, 1954). Observations made on the basis of agrarian textbooks therefore show that wet periods were far more of an issue for the agriculture of the time than dry ones.

\subsection{Data derived from tax registers and inventories of land estates}

The beginning of the modern era was associated with the vast development of bureaucracy and written documentation both at the level of state institutions and of a society engaged in an increasingly commercialized economy. Prominent, among the surviving materials, are tax records maintained and economic inventories conducted at the time by both ecclesiastical and royal 
estates. Unfortunately, the materials relating to the estates of the gentry survived in a fragmentary and very dispersed form, and for this very reason they were not taken into account in our work (Leskiewiczowa, 1953; Maciejewska, 1959).

\subsubsection{Tax registers}

During the 16th century the treasury apparatus in the Kingdom of Poland witnessed a period of intensive modernization (Boroda and Guzowski, 2016). One of its features was the increase in revenue coming from taxes, and one of the most important sources of money was taxation of the area of land cultivated by the peasants (Boroda, 2007). The source materials exhibit a different degree of preservation. Some confirm only the amount of money collected in the country in a given year, others give an idea of the taxed land area in the region, and some make it possible to reconstruct the level of agriculture in each locality. From the perspective of the central state finances, it can be noted that at the beginning of the 16th century taxes yielded on average only about 10,000 florins per year; with the reforms, more revenue was achieved, reaching 55.000-60.000 florins per

170 year $(1514,1520)$, and the exceptionally dry decade did not change this trend. In 1533, more than 70.000 florins were collected, which is as much as was also collected in 1552-1553 (Rutkowski, 1909; Wyczański, 1952; Weyman, 1956). The surviving fiscal materials produced by the central government apparatus thus make it possible to compare, within certain regions, key economic information such as the size of the taxed agricultural acreage or the scale of the milling industry. The number of cultivated fields shows general economic trends in this context, while the number of watermills can be taken as a sensitive indicator related not only to the overall condition of the economy, but also to water levels, which may have been related to the climate changes and weather conditions.

FIGURE 1. Distribution of areas analyzed in the text in the spatial context of Vistula river exports in the 16th century (before the Union of Lublin of 1569).

In this study we have focused on Płock, Brześć, Dobrzyń and Sochaczew lands (Fig. 1), which should be considered particularly important in Poland at that time from the economic point of view. They were located on the Vistula River and therefore had to actively participate in trans-regional trade (Żaboklicka, 1958). The economic information extracted from the summaries was primarily:

a) the acreage of cultivated land where the amount of land cultivated by peasants (lanei kmethonum), village representatives (lanei scultetorum), and land cultivated directly by local gentry (aratura sua) were counted together;

b) the number of watermills divided by ownership structure into mills inherited by miller families (molendina hereditaria) and those leased under temporary contracts (molendina annualia).

It should be noted that the summaries that we have used prevent an analysis of the specific and detailed economic structure of a given region. However, they can be considered a significant support in building a general economic portrait of each region, 
which is important in the context of the lack of adequate treasury sources from the first half of the 16th century. We believe that it was the time of dynamic agricultural growth. In the case of the Brześć Kujawski Land the acreage of arable land increased from 1,928 mansi in 1489 to 2,505.5 in 1533 (Senkowski, 1961). In the Sochaczew Land the growth was even more spectacular - from 752 mansi in 1496 to 2,002.25 in 1533 (Archival Sources 5). It is likely that in the remaining two regions, for which the data are not available, the situation was similar.

FIGURE 2. Changes in cultivated land based on surviving tax summaries from 1533, 1535 and 1543. Sources: Archival Sources 1-3.

The 1530s and 1540s were characterized by relative stability in terms of the acreage of arable land, although a slight downward trend was visible in most regions.

It can be inferred from the tax source data that the highest decrease in arable land (comparing the first and the last summary) was observed in the Brześć Land (8.04\%); in the Dobrzyń Land it was 6.22\% and in the Sochaczew Land 2.88\% (Fig. 2). This means that the gradual decrease in cultivated land could be interpreted as an effect of land degradation and settlement processes related to the three-field system economy (Newman and Harvey, 1997). The only increase in land acreage took place in the Płock Land and amounted to $1.68 \%$, which should be interpreted as a modest attempt to acquire new land, probably at the expense of the forest network (Gidaszewski et al., 2013). Unfortunately, the summaries from the areas discussed here did not include any information on deserted fields. The lack of this information prevents us from fully confirming these observations. Statistics related to the number of watermills in each of the mentioned lands can also be an important tool (Fig.2). The variation in the number of watermills was usually closely related to the amount of acreage under cultivation (Związek, 2014). In the Brześć and Płock lands, an increase in the number of watermills was observed, ranging from 4 to 8\%; in the Dobrzyń Land, the increase was the most spectacular and amounted to $100 \%$ (from 44 to 88 mills). Only in the Sochaczew Land the number of watermills decreased by about $4 \%$. Additionally, data from the summaries provide us with information showing the ongoing reconstruction of the economic structure of water mill ownership from hereditary to leased (in the Brześć, Dobrzyń, and Płock lands) and from leased to hereditary in the Sochaczew Land. With the present state of our knowledge, it should be assumed that the system based on temporary leases was more advantageous from the point of view of land ownership (Kaczmarczyk, 1910; Trawkowski, 1960; Guzowski, 2020) because it enabled better management and adaptation to various fluctuations probably including economic ones resulting from climate change during the Little Ice Age. However, this issue requires further and more detailed research.

\subsubsection{Great estate inventories}

The 16th century was a period of development of manorial economy in estates belonging to large landowners in the Polish Kingdom (Cerman, 2012; Słoń, 2014). Data concerning inventories of landed estates from the first half of the 16th century can be divided into three main types. First, there is information concerning the economic status of the Malbork Royal Economy 
https://doi.org/10.5194/cp-2021-157

Preprint. Discussion started: 29 November 2021

(c) Author(s) 2021. CC BY 4.0 License.

\section{(c) (1)}

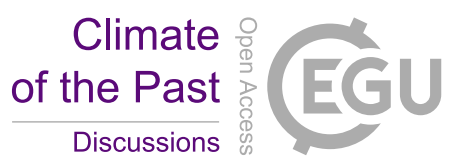

(MRE), for which the longest and most complete series of data has been preserved (Szpak, 1971). These data were supplemented by eight series of inventories of manors that were part of the royal estates (Wawrzyńczyk, 1974). We also used two series of data on the inventories of the bishops of Włocławek from the early 1530s. (Żytkowicz, 1962).

Most of the estates used in our analyses were located in the basin of the Vistula River, which was then the most important navigable trade route. We presented our data in the form of sets expressed in so-called kopy, and using the grain yield ratio (GYR). The GYR gives us an idea of the economic level of the goods concerned and, on a broader scale, of the overall level of agricultural production in the period in question. It also gave us the possibility to compare the cereal production between particular regions (Wawrzyńczyk, 1960; Wyczański, 1968). All data under scrutiny were also placed in a wider time context. Therefore, we used all information from before and after the studied decade from 1531 to 1540 to track the changes within the economy of kings' and ecclesiastical estates. In this view, all later inventories from the mid-1560s have been treated as reference points in our analysis. However, we were forced to omit the Red Ruthenian lands and partially Greater Poland, whose level of description at the time was far from perfection (Wawrzyńczyk, 1974).

\subsubsection{Malbork Royal Economy (MRE) and other royal estates}

The first area for which we have an extant and abundant set of inventory sources is the area of MRE covering a large part of 240 Vistula Fens (Pol. Żuławy Wiślane) surrounding the former capital of the Teutonic State - Marienburg (Pol. Malbork). As a result of intensive German colonization in this region between the late 13th and the late 14th centuries, this area underwent intensive landscape changes involving adaptation of the site for agricultural purposes. Protected from floods by dikes constructed before the end of the 14th century, it was abundant in water and rich in river silts, which were ideally suited to arable farming and animal husbandry (Bertram et al., 1923); this is confirmed by rather laconic references in sources describing

245 the land there as 'good' or 'comely' (Hoszowski, 1961). High profits obtained by royal administrators from fields and pastures situated mainly between the Vistula and Nogat rivers were one of most important reasons for establishing the royal economy in that area in 1511. Its agricultural potential was effectively used in subsequent decades, especially since the late 1550s, when the area became subject to intensive Hollander (Dutch-type) colonization and, consequently, turned to a technical revolution, which involved the construction of drainage canals in the Vistula Fens and subjecting the water flows to strict control (Ludwig, 1961).

FIGURE 3. Vistula Fens settlement

The source information on the economic condition of the MRE is extremely rich (Szpak, 1971). It should be noted, however, that in the estate, unlike in other parts of the Crown, rye did not play the main role in agricultural production. Wheat and barley were definitely in the lead. Jan Szpak (1972) claimed that it was probably a direct result of a deliberate policy of the estate management based on environmental experiments. The researcher pointed out that the administrators of manor estates were to a large extent guided by the natural fertility of particular soils, and adjusted the appropriate share of particular crops to their 
quality. Wheat and barley grew mainly on better soils, whereas rye and oats on weaker ones. The agricultural potential of this area was supported by the occurrence of fertile soils like Dystric/Eutric Fluvisols and Cambisols (Dobrzański et al., 1974; IUSS Working Group WRB, 2015).

Our data on crop yields from the MRE concern basic crops and peas. They show that the decade from 1531 to 1540 was the time of exceptionally abundant wheat, barley, rye and oats harvests, much more abundant than in the early 16th century as well as in the following decades (Figure 4). Peas harvests were growing consistently over the first half of the 16th century, including the 'drought decade' and the ensuing one.

FIGURE 4. Grain yield ratio of main crops in Malbork Royal Economy. Sources: (Szpak, 1971).

The increase in agricultural productivity can also be seen in the growing volume of cereal harvests. In the period from 1531 to 1540 they were significantly more abundant than at the beginning of the century. Despite some decline at the beginning of the 1540 s, also at the end of this decade they were better than in the years preceding the 'drought decade' (Figure 5). The increase took place in spite of reductions in the acreage of arable land. In the years 1521-1530 the acreage fell to 97\% of the area from the beginning of the century, and in the decade from 1531 to 1540 to $85.7 \%$, with a gradual increase in the amount of land lying fallow (Szpak, 1971).

FIGURE 5. Volume of grain harvests in Malbork Royal Economy (calculated in coreti; 1 coretus $=55$ litres). Sources: (Szpak, 1971)

Unfortunately, our data from other royal estates are less complete than the ones cited above. Some fragmentary information comes from eight estates which were owned by Polish monarchs at the time (Wawrzyńczyk, 1974). What is available does not permit any conclusive estimates of harvests before the 'drought decade'. The data do show that the 1530s were characterized by lower harvests than the consecutive decades of the 16th century. However, this does not necessarily have to be the result of dry weather, but may simply reflect a lower level of development of manorial farms and less advanced manuring than in the 1560s (Fig 6.).

FIGURE 6. Grain yield ratio of main crops in the royal estates. Sources: (Wawrzyńczyk, 1974).

\subsubsection{Estates of Wloclawek bishops}

The last series of inventory data is information on sowings and yields on the estates of the bishops of Włocławek in two complexes located in Kuyavia (Raciążek, Włocławek). These data, together with a basic historical and economic analysis, come from a compilation published many years ago by Leonid Żytkowicz (1962). When describing the inventories of the 
https://doi.org/10.5194/cp-2021-157

Preprint. Discussion started: 29 November 2021

(c) Author(s) 2021. CC BY 4.0 License.

\section{(c) (i)}

estates of the bishops of Włocławek, Żytkowicz paid special attention to the source context. For the 1530s, very detailed accounts concerning grain from the manors of various estate keys have been preserved (Regestra rationis factae de frumentis praediorum). According to this researcher, they can be treated as a firm source concerning the ways in which the bishops of Włocławek managed their estates. This naturally reflects on the degree of reliability of our analysis. In the present work we have used all the data preserved and published by Żytkowicz from the 1530s and subsequent years (1565, 1566 and 1582$)$. The analyses conducted by Żytkowicz show several elements which are important from our point of view. First of all, a relatively high proportion of manorial farms in relation to peasant holdings, especially in the Włocławek and Raciąż keys. This is a fair conclusion, considering the fact that these two keys were located close to the Vistula River, which made it easy for them to be included in the long-distance Vistula trade.

Żytkowicz also pointed out that in the estates of the bishops of Włocławek the most frequently cultivated cereals were rye and oats, which (depending on the period) constituted $85-89 \%$ of all production. He explains such a structure of cultivation mainly by two factors: 1) the permanent shortage of manure (which was, among other things, the result of a bad breeding policy) and

2) the relatively poor soils, which became sterile very quickly. The main soil types in this area are the sandy Brunic Arenosols and Podzols, the more fertile Luvisols and the locally encountered Gleyic/Stagnic Phaeozems or Gleyic/Stagnic Chernozems (IUSS Working Group WRB, 2015). It can be inferred from the yields obtained in both estates of the bishops of Włocławek that they were the lowest in comparison with royal estates at that time, which was also pointed out by Żytkowicz. Perhaps this was the reason why they were leased out in 1584, when the economy of these estates suffered a serious collapse. It should be noted, however, that fragmentary data from the years 1531-1534 indicate a slight increase in yields in the estates belonging to the bishops of Włocławek situated in Cuyavia.

FIGURE 7. Grain yield ratio in the estates of the bishops of Włocławek. Source: (Żytkowicz, 1962).

\subsection{Data on fires in cities and towns}

Recently, it has been argued that there is a strong causal correlation between extreme droughts and occurrence of fires in cities

315 and towns of the pre-industrial era (Mauelshagen, 2010; Parker, 2013; Nowosad and Oliński, 2020). To verify this hypothesis, we have collected data on urban fires from the reign of Sigismund the Old (1507-1548) using the so-called Crown Metric (Pol. Metryka Koronna, hereinafter CM), i.e. the royal chancery registers recording charters, privileges, acts, letters and other documents issued in the name of the king by royal officials (Sułkowska, 1961; Sułkowska-Kurasiowa, 1966). As by the 16th century, it had become mandatory to record all the issued documents in the CM, it is assumed that its volumes from that time contain the vast majority of royal grants. We have focused on tax exemptions and concessions given to towns affected by fires as they were awarded on request (made mostly by town councils but in some cases also by town owners or individual burghers). Assuming that almost all urban centres impacted by a fire applied for such a privilege, we argue that this type of data provides the most consistent (both temporally and geographically) and reliable evidence for the quantitative analysis. Moreover, a comparison of the length of exemption periods allows us to evaluate, to some extent, the severity of a particular incident. Some 
https://doi.org/10.5194/cp-2021-157

Preprint. Discussion started: 29 November 2021

(c) Author(s) 2021. CC BY 4.0 License.

\section{(c) (i)}

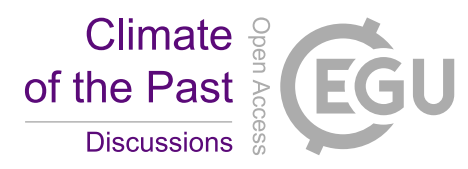

inconsistencies might be caused by the initial lack of tax exemptions for towns of the Duchy of Mazovia, which until its incorporation into the Crown of Poland in 1526 had a different administrative, fiscal and economic system (Senkowski, 1965). In most cases, the documents contain no extensive direct information about the fires. Only incidentally do they describe the area of a town that was damaged or provide an exact date of the incident. Nonetheless, common expressions such as 'nuper' 'recently' (e.g. CM 31:230-231, CM 48:80-81), 'non pridem' - 'not long ago' (e.g. CM 48:61-62; CM 70:562), 'novissima ignis voragine' - 'the newest blaze' (CM 50:400-402) and relative efficiency of the official apparatus lead to the conclusion that the privileges were granted soon after a fire occurred. For instance, when a part of Cracow burnt down on 24 April 1528, the relevant exemption was issued on 28 May by the king, who was then in Vilnius (630 km in a straight line from Cracow) (Piekosiński, 1885). Similarly, the concession for Wschowa, which was destroyed with its suburbs by a conflagration on 6 June of the next year, was granted about a month later also in Vilnius (ca $670 \mathrm{~km}$ away from the town) (CM 44:387-389).

335 Between 1507 and 1548, we identified 226 individual instances of urban fires which resulted in granting a tax exemption. The number of documents relating to them was higher as some privileges were repeated or recorded more than once, different concessions were given by more than one deed or the time of exemption was later extended by another act. In four cases there is no information about the length of the liberty period (CM 47: 408; CM 35: 746-747; CM 70: 223-223a). Formulae of the exemption clause varied from quite general ('liberty from a contribution called schoss for six years', CM 51:216, transl. from

340 Latin) to very detailed ('liberty from all rents, charges, contributions and levies which for us or the commonwealth were constituted or in future will be constituted', CM 23:215, transl. from Latin). They commonly consisted of more than one stipulation, often with a different free period for particular provisions: 'liberty from the rents that they pay for their dwelling plots or houses as well as from the civil levies, commonly called schoss, and from all the other public levies and contributions that were constituted or will be constituted for ten years; from the rents paid for fields for four years; from civic transport duties for three years; from the liquor tax (Pol. czopowe) for two quarters of a year' (CM 36:165-166, transl. from Latin).

FIGURE 8. Number of fires registered in Crown Metric. Source: Archival Sources 4.

The number of tax exemptions connected with fires between 1531 and 1540 was greater than in the earlier and later periods, although the growth by $30 \%$ was not alarming. Moreover, data show that the single year with the largest number of fires in the first half of the 16th century was not any year in the 'drought decade' but 1522. Meanwhile, in 1540, which was seen as exceptionally dry, there were only five tax exemptions related to damage caused by fire.

For the comparative analysis, we used the highest number of years of liberty granted for each incident, regardless of the concession type. In the vast majority of cases, however, the longest liberty period was granted for schoss, which was the basic tax (wealth tax) paid by burghers in Poland. Moreover, the longer the primary exemption period, the more of various stipulations were typically included. Although some municipal authorities or town owners were probably able to obtain a longer exemption or a greater number of concessions owing to better relations with the royal apparatus, it seems that those variations were not extreme and not common. Therefore, the length of the principal liberty is a good indicator of the fire 
severity, as it was mainly determined by the destruction caused by each incident. Using that measure, we have divided the recorded fires into three fire severity categories (FSC) (Figure 9). The year range of each category was defined taking into account the types of stipulations and the context provided by the documents. FSC 1 - localized/small fires: a short period of exemption $(0 *-5$ years, $* 0$ denoting a period shorter than a year), in the majority of cases only one type of concession granted, the liberty given predominantly to those affected by the fire, mentions of individual burghers who lost their property or terms such as 'in quadam parte conflagravit' - 'a certain [suggesting non-substantial] part [of a town] burnt down' (e.g. CM 36:815); FSC 2 - substantial fires affecting a large part of a town: a medium period of exemption (6-9 years), commonly more than one type of concessions, some liberties granted to the whole urban community, terms such as 'in magna parte' - '[burnt] in a great part' (e.g. CM 45:295-296), 'in non mediocre et maxima parte' - '[burnt] in not an insubstantial, in the greatest part' (e.g. CM 23:50); FSC 3 - major/severe fires affecting the majority of the urban fabric: a long period of exemption (more than 10 years), several different concessions, some period of liberty given to the whole community, additional stipulations providing means for rebuilding municipal buildings and private property (e.g. timber from royal forests), terms such as 'totius civitatis conflagratio' - 'conflagration of the whole city' (CM 35:924-925), 'totum conflagravit' - 'the whole [town] burnt down' (CM 33: 349-350).

The analysis reveals that the decade from 1531 to 1540 did not exhibit any exceptional fire severity. On the contrary, it can be concluded that in spite of a larger number of fire outbreaks, their severity was lesser than in the preceding and following decades.

FIGURE 9. Index of fire severity categories. Source: Archival Sources 4.

FIGURE 10. Spatial distribution of tax exemptions for cities and towns due to the fires. Source: Archival Sources 4.

\subsubsection{Can we treat urban fires as a climate proxy?}

As pointed out in the previous chapter, it became common to associate fires of the pre-industrial period with climate factors. Even short spells of extremely high temperatures, droughts and wind are described as critical causes of conflagrations in medieval and early urban centres (Mauelshagen, 2010). We argue, however, that our analyses show that there is little or no correlation between dry and hot periods of weather and the occurrence of urban fires (Fig. 11). These climate factors were not the source of conflagrations.

FIGURE 11. Number of fires and PDSI. Source: Archival Sources 4 and (Cook et al., 2015).

There were instances in which a blaze was started by a natural phenomenon, i.e. a lightning (e.g. Biała in 1518, CM 31: 329; 390 Stężyca 1540, CM 57: 291); yet, fires cannot be linked with the direct influence of the climate change. In most cases, a fire was directly caused by human activity and negligence. In the CM, there are safe-conduct documents issued for burghers who 
https://doi.org/10.5194/cp-2021-157

Preprint. Discussion started: 29 November 2021

(c) Author(s) 2021. CC BY 4.0 License.

\section{(c) (i)}

were accused of starting a blaze or in whose property a fire originated (e.g. CM 37: 453v-454, CM 23:523, CM 31:499). Involuntary conflagrations were very common, especially as daily home activities (e.g. cooking) as well as the majority of crafts (e.g. baking, brewing, smithing, textile and leather production) were related to dealing with fire, and often with the open one. It is reflected in the substantial share of municipal regulations relating to fire hazards, prescribing specific ways of dealing with the open fire, regulating times and circumstances of using artificial light, etc. (Zajęcki, 2014; Modrzyński, 2017). Some urban fires also resulted from hostilities and war. In the case of 16th century Poland, this concerned mainly the south-eastern part of the country, but it could have a huge impact on the total number of fires recorded for a particular year. For instance, in 1524 , out of ten tax exemptions granted to towns in relation to fires, at least four were connected with the Tatars' invasion (Leżajsk, CM 38: 66-70; Mościcka, CM 44: 475; Stryj, CM 38: 71; Strzerzec CM 29: 400, CM 38: 95 and CM 47: 246v-247). A similar situation occurred in 1509 (2 of 10 - Dobrotwór, CM 23: 574; Kamionka, CM 23: 575 and CM 63: 154) and 1538 (2 of 12 - Satanów, CM 55: 23; Zinków, CM 39: 765-766; CM 55: 23).

High temperatures, low humidity and prolonged lack of rain were not among the major factors contributing to fire spread and acceleration. Weather could impact fire conditions to some extent. Garrioch points out (after S.J. Pyne) that in northern and central Europe, raging fires broke out during winter months, when it was cold and wet (Garrioch, 2019). In his examples of Stockholm and Vienna, however, the disparity in the number and severity of fires should be attributed to a snow cover acting as a natural insulation layer rather than to simply wet conditions. Nonetheless, we, as did Garrioch, argue that the dominant element affecting the flammability of towns was the characteristic of the urban built environment. Medieval and early modern towns, especially the larger ones, were often densely built up, with the majority of urban fabric consisting of timber buildings (with wooden shingles and thatching as the most common roofing) (Schofield and Vince, 2005; Samsonowicz and Bogucka, 1986) and large quantities of combustible materials stored on each dwelling plot (e.g. firewood, hay). Even the Polish royal capital city of Cracow is considered to be predominantly built of timber in the 16th century - houses on the plots adjacent to the main square were constructed of stones or bricks, but the greater the distance from the city centre, the more dominant wood became (Follprecht and Noga, 2014). Moreover, masonry structures commonly occupied only the front parts of the dwelling plots of European urban centres, while their rear areas were often covered with wooden sheds, storages, fences and facilities such as kilns, hearths and ovens (Schofield and Vince, 2005). The main role of the building materials in the combustibility of the urban fabric was recognized by municipal authorities in their ordinances. They obliged burghers to construct firewalls and prohibited storing of highly flammable materials in the towns. They also stipulated that each property had to be furnished with leather buckets and pike poles used for knocking the burning structures down to prevent the further spread of a fire as well as compelled town inhabitants to participate in firefighting (Sowina, 2002; Modrzyński, 2017). The importance of improving the building materials was also underlined in the royal tax exemptions, with substantial extension of the liberty period for burghers willing to rebuild their property in stone or brick (e.g. Oświęcim 1519, CM 31: 501-503; Poznań 1536, CM 51: 237v-238; respectively, from 14 to 18 years and from 10 to 20 years). It should be stressed that although droughts and high temperatures may affect the flammability of timber structures, their impact on acceleration and spreading of flames is marginal - buildings 
https://doi.org/10.5194/cp-2021-157

Preprint. Discussion started: 29 November 2021

(c) Author(s) 2021. CC BY 4.0 License.

(c) (i)

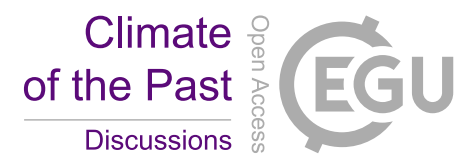

and whole towns could have easily burnt down during thunderstorms accompanied by heavy rain. The only weather factor that played a critical role in the acceleration and spreading of flames was wind.

\subsection{Product prices}

Data on grain and beer prices in the largest Polish cities compiled by historians reflect the market situation prevailing in them. In the case of the Kingdom of Poland, the grain market, which was also the basis for beer production - the basic drink of society at the time - was a free market in which all social groups could participate. In the first half of the 16th century the Polish grain market became increasingly integrated with the European market, but in the years under review the economic base of Gdańsk (and its exports) was mainly Pomerania and its immediate neighbours: Cuyavia and Mazovia, connected to the largest Polish port by a waterway, the Vistula River (Mielczarski, 1962; Guzowski, 2011). First of all, the prices of oats and rye were taken into account (Fig. 12), i.e. the most important cereals on the Polish market, being the basic feed cereal (oats)

435 and the main element of human diet (rye). Oats were produced and sold on local markets, so their prices reflect the situation undisturbed by export impulses. Rye was exported to a greater extent (wheat as well), although it can be concluded that external demand in the period under review influenced only prices in Gdańsk, while prices in Cracow and Lviv represent a regional situation. In the case of the three large cities for which data are available, we can assume that the market situation in the period from 1520 to 1550 was enduring. The hottest decade is not distinguished by an exceptional rise in the prices of either rye or

440 oats, rather a gentle upward trend can be observed throughout the period which can be linked to an increase in demand due to population growth.

FIGURE 12. Prices in Cracow, Gdańsk and Lviv. Source: (Pelc, 1935, 1937; Hoszowski, 1928).

445 However, quarterly prices are more important for determining the seasonal fluctuations of agricultural production. For the purposes of our research, we have analyzed how the value of agricultural products changed in the fourth quarter relative to the average price in the preceding quarters. An increase in the prices after the harvest, when most of the crop was coming to market, would indicate a poor harvest and a definite excess of demand over supply. The data shown in the graph usually indicate the opposite situation, where prices tend to fall, with the exception of years with extraordinary increases. It should be noted at this point that in the decade from 1531 to 1540 there were no more such seasons than in the preceding and following decade; moreover, if a certain decline in production should be referred to, it occurred in different years for different regions, which means that in the case of a potential crisis in production, regional variations must be taken into account. As regards the grain prices in the case of Cracow (because the gathered prices made it possible only there), an observation was added on the price trend of peas, characterized by different weather requirements than for grain (Fig. 13). In order for peas to yield well, they had to be sown in the spring into moist, undrained soil. The prices of peas in Cracow point to a potentially successful harvest of this crop. The years 1532 and 1533 (market in Cracow, rye prices) and 1549-1550 (market in Cracow and Lviv, peas, rye, oats) are considered less fertile years. 
FIGURE 13. Quarterly prices in Cracow. Source: (Pelc, 1935).

Consequently, an upward trend in beer prices or at least a stable situation over the years 1521-1550 are by no means surprising; in Lviv, even a decline can be observed in the 1530s, although this conclusion may be distorted by the quality of data (prices recorded for only two years) (Fig. 12). More pronounced is the increase in the prices of wine imported to Poland from abroad (from Hungary and Germany), although even in this case, an upward trend characteristic of the entire period under consideration can be seen, in which the decade from 1531 to 1540 does not stand out (Fig. 14). On the contrary, a slight decline in prices on the large Wrocław market can be observed. At that time, the Wrockaw market was dominated by the consumption of imported wine. From the mid-15th century, along with the change in Silesia's affiliation to the monarchy of Matthias Corvinus, the share of Hungarian wines and small-medium wines imported via Hungary gradually increased, while the popularity of Alpine wines continued unabated (Myśliwski, 2009). To a small extent, domestic wines were present on the market, as most of the crops had already declined in the 15th century. Single vineyards (near Środa Śląska or near Wrocław) satisfied only liturgical needs, and the must found its way to the tables of monasteries (Adamska, 2017). The decade from 1531 to 1540 also saw stable wine prices at a level not exceeding 2 grosze per 1 quart. What is more, even a slight decline in prices in the years 1532-1536 can be observed, along with an equally slight increase in subsequent years (Wolański, 1996).

\subsection{Polish grain exports in Gdańsk}

In the 16th century Gdańsk was a monopolist in the exports of Polish products to the west of Europe, participating successfully in international trade and maintaining close contacts with the main Dutch and English centres (Bogucka, 1970). The city benefited from the fact that Poland of the 16th century became the 'granary of Europe', which means that most of the grain arriving in Gdańsk down the Vistula River was traded on the markets of Western Europe (Batou and Szlajfer, 2010; Samsonowicz, 1956). Apart from grain (mainly rye), the Gdańsk market also exported industrially important raw materials (wood, ash, tar, pitch, wax and wool). Unfortunately, for the first half of the 16th century only rudimentary data are available on the volume of Polish grain exported by Gdańsk, although it seems that from the end of the Middle Ages there was an upward trend (Fig. 15).

FIGURE 15. Grain exports from Gdańsk. Source: (Samsonowicz, 1956; Kutrzeba and Duda, 1915).

Slightly more information on the development of trade contacts between the ports of the south-eastern Baltic is provided by the registers of the Sundtolls recording the number of ships from individual ports crossing the Danish straits (Ellinger and 
https://doi.org/10.5194/cp-2021-157

Preprint. Discussion started: 29 November 2021

(c) Author(s) 2021. CC BY 4.0 License.

(c) (i)

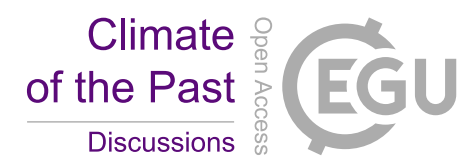

Korst, 1906) (Fig.16). In the fourth decade of the 16th century, despite a visible slump in 1540 (and the following year), on average slightly more ships sailed annually from Gdańsk and Ducal Prussia than in the earlier and later periods. Thus, a decadelong crisis in trade cannot be referred to based largely on agricultural products, although the crisis years of 1540-1541 certainly stand out in a negative fashion. A similar trend is also evidenced by the registers of the water chamber in Włocławek, preserved from 1537. They too imply a decline in both the number of ships and their capacity after 1540 (Fig 17).

FIGURE 16. Ships from Polish and Prussian ports registered in the Sundtolls. Source: (Ellinger and Korst, 1906).

FIGURE 17. Number of ships registered in the Włocławek water chamber. Source: (Kutrzeba and Duda, 1915).

\section{Conclusions}

Our observations show that narrative texts, which have so far been used in many works on historical climatology, should not be used as the only indicator for studying the resilience of ancient societies to weather and climate change. By using different series of economic data we were able to show that the former economy of the Polish lands, based mainly on the production and exports of cereals, coped quite well with periods of drought in the decade from 1531 to 1540. Our observations have highlighted that written sources recording the condition of the core branch of the preindustrial Polish economy do not show signs of any particular agricultural crisis in the 'drought decade'. It can be explained by the fact that the most commonly grown and consumed crops were rye and oats, which are resistant to difficult winter conditions and dry weather. Neither of the cereals requires good soils or much manure, either. This made it possible not only to obtain relatively high yields, but also to better manage the valuable manure, which could then be used to enrich wheat, barley or garden crops with nutrients.

Also, the system based mostly on lump-sum levies in individual tax categories was not too burdensome for peasants, gentry or clergy. It left quite a lot of money on the market, allowing the accumulated capital to be effectively used on local markets and providing a sufficiently large economic security in case of possible crises.

515 Our observations have also shown that the automatic linking of dry periods with urban fires present in the literature is a gross oversimplification of the situation at the time. Previous researchers writing on the subject have not taken into account several of the obvious issues with the functioning of cities and towns in the Middle Ages and Early Modern times in the context of the history of material culture, e.g. the type of construction material from which the buildings were made. Observations made on the basis of a series of detailed data preserved in the CM indicate that there was no relationship between droughts and the occurrence of town fires. But does this mean that droughts did not cause fires during dry periods? They did, but first of all, people were to blame for the outbreak of fires in urban centres, and next, nature could be blamed (e.g. the outbreak of fire in 
https://doi.org/10.5194/cp-2021-157

Preprint. Discussion started: 29 November 2021

(c) Author(s) 2021. CC BY 4.0 License.

(c) (1)

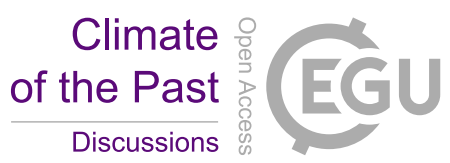

the city or town due to a lightning). The weather conditions could have a much stronger impact on non-urban fires - forests, fields and meadows; yet, at this stage of the research into this topic, quantitative evidence is lacking.

It must also be added that the only crisis actually visible in the collected source material concerns the consequences related to

525 the drought of 1540. In our opinion, this opens up completely new possibilities of interpretation related to this event, and potential new research questions should be asked about how the extreme weather events of 1540 affected the economic stability of Europe in the long term. Our research has also shown that in-depth economic analyses inspired by climatological studies make it possible to better understand the complex relationship between humans and the environment in the past.

\section{Acknowledgements}

Our sincere thanks are due to: Stephen Gadd, Andrzej Gliwa, Dorota Dias-Lewandowska, Niels Petersen, Andras Vadas, Michał Słowiński, Edyta Regulska, Marta Piber-Zbieranowska, Andrzej Buczyło and Mark Whelan for the comments, suggestions and support that we received while working on this article.

\section{Funding}

TZ and PG are grateful for the financial support from National Science Centre (NCN) grant no. 2017/27/L/HS3/03242. MKS funded her research from National Science Centre (NCN) grant no. 2018/31/HS3/02187.

\section{Authors' contribution}

540 TZ and PG designed the study. RP provided the statistical analysis and prepared all statistical graphs. TZ, PG, MTR, MK-S, MT, and DA provided the historical analysis. TP prepared all cartographical figures. SS and BK supplemented the text with regard to the soil and climate context. All authors discussed the methods and results, and commented on the manuscript. 
https://doi.org/10.5194/cp-2021-157

Preprint. Discussion started: 29 November 2021

(c) Author(s) 2021. CC BY 4.0 License.

(c) (i)

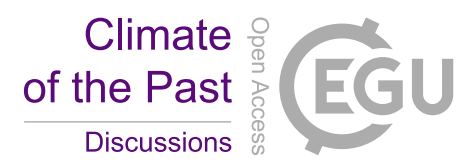

\section{Archival Sources}

AS 1 - Ratio facta cum omnibus exactoribus de omnibus et singulis exactionibus publicis [1533] in: AGAD, Archiwum Skarbu Koronnego I 35, ff. 202-255.

AS 2 - Ratio facta cum omnibus exactoribus de omnibus et singulis exactionibus publicis [1535] in: AGAD, Archiwum Skarbu Koronnego I 2, ff. 145-166.

550 AS 3 - Suscepcio racionum ab exactoribus Regni anni Domini 1543 in: AGAD, Archiwum Skarbu Koronnego I 61, ff. 766-805.

AS 4 - Kings' tax exemption privileges in: AGAD, Metryka Koronna (Crown's Metric), No. 23, 24, 25, 26, 28, 30, 31, 35, $36,38,39,40,42,46,47,48,49,50,51,52,61,63,70$.

AS 5 - Sochaczew tax register from 1496 in: AGAD, Archiwum Skarbu Koronnego I 48, ff. 49-53.

\section{References}

Adamska, D.: Winnice na Przedgórzu Sudeckim. W sprawie uprawy winorośli na średniowiecznym Śląsku, in: Cum gratia et amicitia. Studia z dziejów osadnictwa dedykowane Pani Profesor Marcie Młynarskiej-Kaletynowej z okazji 65-lecia działalności naukowej, Adamska, D., Chrzan, K., Pankiewicz, A. (Eds.), Wrocław, 253-267, 2017.

Al-Kayssi, A. W., Al-Karaghouli, A. A., Hasson, A. M., and Beker, S. A.: Influence of soil moisture content on soil temperature and heat storage under greenhouse conditions, Journal of Agricultural Engineering Research, 45, 241-252, doi:10.1016/S0021-8634(05)80152-0, 1990.

Batou, J. and Szlajfer, H. (Eds.): Western Europe, Eastern Europe and world development, 13th-18th centuries: collection of essays of Marian Małowist, Brill, Leiden, 2010.

Bertram, H., La Baume, W., and Klöppel, O.: Das Weichsel-Nogat-Delta. Beiträge zur Geschichte seiner landschaftlichen Entwickelung, vorgeschichtlichen Besiedelung und bäuerlichen Haus- und Hofanlage, Danzig, 1923.

Bogucka, M.: Gdańsk - Polski czy międzynarodowy ośrodek gospodarczy?, in: Polska w epoce odrodzenia. Państwo społeczeństwo - kultura, Wyczański, A. (Ed.), Warszawa, 100-125, 1970.

Boroda, K.: Kmieć, łan czy profit? Co było podstawą poboru łanowego w XV i XVI wieku?, in: Człowiek wobec miar i czasu w przeszłości, Guzowski, P., Liedke, M. (Eds.), Kraków, 152-170, 2007.

Boroda, K.: Komu i do czego potrzebne były w XVI wieku sumariusze podatkowe? O narodzinach planowania budżetowego we wczesnonowożytnym Królestwie Polskim, Roczniki Dziejów Społecznych i Gospodarczych, 73, 29-50, 2013.

Boroda, K.: Geografia gospodarcza Królestwa Polskiego w XVI wieku, Białystok, 2016.

Boroda, K. and Guzowski, P.: From King's Finance to Public Finance. Different Strategies of Fighting Financial Crisis in the Kingdom of Poland under Jagiellonian Rule (1386-1572), in: La fiscalità nell'economia Europea secc. XIII-XVIII.

575 Fiscal systems in the European economy from the 13th to the 18th centuries, Cavaciocchi, S. (Ed.), Firenze, 451-470, 2016. 
https://doi.org/10.5194/cp-2021-157

Preprint. Discussion started: 29 November 2021

(c) Author(s) 2021. CC BY 4.0 License.

\section{(c) (i)}

Brázdil, R., Dobrovolný, P., Bauch, M., Camenisch, C., Kiss, A., Kotyza, O., Oliński, P., and Řezníčková, L.: Central Europe, 1531-1540 CE: The driest summer decade of the past five centuries?, Clim. Past, 16, 2125-2151, doi:10.5194/cp-16-2125-2020, 2020.

Brázdil, R., Dobrovolný, P., Trnka, M., Kotyza, O., Řezníčková, L., Valášek, H., Zahradníček, P., and Štěpánek, P.: Droughts in the Czech Lands, 1090-2012 AD, Climate and Past, 9, 1987-2002, 2013a.

Brázdil, R., Kiss, A., Luterbracher, J., Nash, D. J., and Reznícková, L.: Documentary data and the study of past droughts: a global state of the art, Climate of the Past, 14, 1915-1960, 2018.

Brázdil, R., Kotyza, O., Dobrovolný, P., Řezníčková, L., and Valášek, H.: History of weather and climate in the Czech lands, History of Weather and Climate in the Czech Lands, 10, Masaryk University, Brno, 285 pp., $2013 \mathrm{~b}$.

Büntgen, U., Tegel, W., Carrer, M., Krusic, P. J., Hayes, M., and Esper, J.: Commentary to Wetter et al. (2014): Limited tree-ring evidence for a 1540 European 'Megadrought', Climatic Change, 131, 183-190, doi:10.1007/s10584-015-1423$1,2015$.

Camenisch, C., Brázdil, R., Kiss, A., Pfister, C., Wetter, O., Rohr, C., Contino, A., and Retsö, D.: Extreme heat and drought in 1473 and their impacts in Europe in the context of the early 1470s, Reg Environ Change, 20, doi:10.1007/s10113020-01601-0, 2020.

Camenisch, C., Keller, K. M., Salvisberg, M., Amann, B., Bauch, M., Blumer, S., Brázdil, R., Brönnimann, S., Büntgen, U., Campbell, B. M. S., Fernández-Donado, L., Fleitmann, D., Glaser, R., González-Rouco, F., Grosjean, M., Hoffmann, R. C., Huhtamaa, H., Joos, F., Kiss, A., Kotyza, O., Lehner, F., Luterbacher, J., Maughan, N., Neukom, R., Novy, T., Pribyl, K., Raible, C. C., Riemann, D., Schuh, M., Slavin, P., Werner, J. P., and Wetter, O.: The 1430s: a cold period of extraordinary internal climate variability during the early Spörer Minimum with social and economic impacts in northwestern and central Europe, Clim. Past, 12, 2107-2126, doi:10.5194/cp-12-2107-2016, 2016.

Cerman, M.: Villagers and lords in Eastern Europe, 1300-1800, Studies in European History, Palgrave Macmillan, Basingstoke, New York, XVII, [1], 155 s., 2012.

Chomętowski, W.: Materiały do dziejów rolnictwa w Polsce XVI i XVII wieku. Poprzedzone wiadomością o życiu i pismach Jana Ostroroga wojewody poznańskiego, Warszawa, 1878.

Chuine, I., Yiou, P., Viovy, N., Seguin, B., Daux, V., and Le Roy Ladurie, E.: Historical phenology: grape ripening as a past climate indicator, Nature, 432, 289-290, doi:10.1038/432289a, 2004.

Cook, E. R., Seager, R., Kushnir, Y., Briffa, K. R., Büntgen, U., Frank, D., Krusic, P. J., Tegel, W., van der Schrier, G., Andreu-Hayles, L., Baillie, M., Baittinger, C., Bleicher, N., Bonde, N., Brown, D., Carrer, M., Cooper, R., Čufar, K., Dittmar, C., Esper, J., Griggs, C., Gunnarson, B., Günther, B., Gutierrez, E., Haneca, K., Helama, S., Herzig, F., Heussner, K.-U., Hofmann, J., Janda, P., Kontic, R., Köse, N., Kyncl, T., Levanič, T., Linderholm, H., Manning, S., Melvin, T. M., Miles, D., Neuwirth, B., Nicolussi, K., Nola, P., Panayotov, M., Popa, I., Rothe, A., Seftigen, K., Seim, A., Svarva, H., Svoboda, M., Thun, T., Timonen, M., Touchan, R., Trotsiuk, V., Trouet, V., Walder, F., Ważny, T., 
https://doi.org/10.5194/cp-2021-157

Preprint. Discussion started: 29 November 2021

(c) Author(s) 2021. CC BY 4.0 License.

\section{(c) (i)}

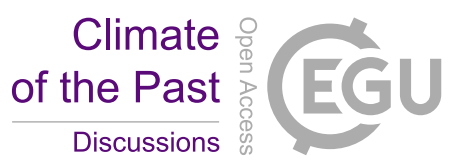

Wilson, R., and Zang, C.: Old World megadroughts and pluvials during the Common Era, Science advances, 1, e1500561, doi:10.1126/sciadv.1500561, 2015.

Cook, E. R., Solomina, O., Matskovsky, V., Cook, B. I., Agafonov, L., Berdnikova, A., Dolgova, E., Karpukhin, A., Knysh, N., Kulakova, M., Kuznetsova, V., Kyncl, T., Kyncl, J., Maximova, O., Panyushkina, I., Seim, A., Tishin, D., Ważny, T., and Yermokhin, M.: The European Russia Drought Atlas (1400-2016 CE), Clim Dyn, 54, 2317-2335, doi:10.1007/s00382-019-05115-2, 2020.

Degroot, D., Anchukaitis, K., Bauch, M., Burnham, J., Carnegy, F., Cui, J., Luna, K. de, Guzowski, P., Hambrecht, G., Huhtamaa, H., Izdebski, A., Kleemann, K., Moesswilde, E., Neupane, N., Newfield, T., Pei, Q., Xoplaki, E., and Zappia, N.: Towards a rigorous understanding of societal responses to climate change, Nature, 591, 539-550, doi:10.1038/s41586-021-03190-2, 2021.

Dobrzański, B., Kowaliński, S., Kuźnicki, F., Witek, T., and Zawadzki, S.: Mapa gleb Polski. Skala 1.000.000, Warszawa, 1974.

Ellinger, N. and Korst, K.: Tabeller over Skibsfart og Varetransport gennem Øresund 1497-1660: del. Tabeller over skibsfarten, 1, 1906.

Follprecht, K. and Noga, Z.: Cracow in 1598, in: Historical atlas of Poland in the 2nd half of the 16th century voivodeships of Cracow, Sandomierz, Lublin, Sieradz, Łęczyca, Rawa, Płock and Mazovia, Słoń, M. (Ed.), Peter Lang, Frankfurt am Main, 692-764, 2014.

Garrioch, D.: Towards a fire history of European cities (late Middle Ages to late nineteenth century), Urban History, 46, 202-224, doi:10.1017/S0963926818000275, 2019.

Geng, S. M., Yan, D. H., Zhang, T. X., Weng, B. S., Zhang, Z. B., and Gang, W.: Effects of extreme drought on agriculture soil and sustainability of different drought soil, 2014.

Gidaszewski, T., Piber-Zbieranowska, M., Suproniuk, J., and Zbieranowski, M.: Transformation of the natural landscapes of the Middle Noteć Region from tenth to the sixteenth century, in: Landscapes and societies in medieval Europe east of the Elbe: interactions between environmental settings and cultural transformations, Kleingärtner, S., Newfield, T. P., Rossignol, S., Wehner, D. (Eds.), Papers in Medieval Studies, 3, Toronto, 245-273, 2013.

635 Gostomski, A.: Gospodarstwo, Wrocław, 1951.

Guzowski, P.: The influence of exports on grain production on Polish royal demesne farms in the second half of the sixteenth century, Agricultural History Review, 59, 312-327, 2011.

Guzowski, P.: Chłopi, czynsze i pieniądze w marksistowskich opisach kolonizacji niemieckiej, in: Marxismus a Medievistika: Společné osudy?, Nodl, M., Węcowski, P. (Eds.), Praha, 143-158, 2020.

640 He, M. and Dijkstra, F. A.: Drought effect on plant nitrogen and phosphorus: a meta-analysis, The New phytologist, 204, 924-931, doi:10.1111/nph.12952, 2014.

Heim, R. R.: A Review of Twentieth-Century Drought Indices Used in the United States, Bull. Amer. Meteor. Soc., 83, 1149-1166, doi:10.1175/1520-0477-83.8.1149, 2002. 
https://doi.org/10.5194/cp-2021-157

Preprint. Discussion started: 29 November 2021

(c) Author(s) 2021. CC BY 4.0 License.

\section{(c) (1)}

Hoszowski, S.: Ceny we Lwowie w XVI i XVII wieku, Lwów, 1928.

645 Hoszowski, S.: Lustracja województwa malborskiego i chełmińskiego 1565, Gdańsk, 1961.

Huhtamaa, H. and Helama, S.: Distant impact: tropical volcanic eruptions and climate-driven agricultural crises in seventeenth-century Ostrobothnia, Finland, Journal of historical geography, 57, 40-51, doi:10.1016/j.jhg.2017.05.011, 2017.

IUSS Working Group WRB: World Reference Base for Soil Resources 2014, update 2015. International soil classification system for naming soils and creating legends for soil maps., World Soil Resources Reports, 106, Rome, 2015.

Kaczmarczyk, K.: Ciężary ludności wiejskiej i miejskiej na prawie niemieckim w Polsce XIII i XIV w., Przegląd Historyczny, 11, 12-30, 1910.

Kiss, A.: Weather and weather-related natural hazards in medieval Hungary II: documentary evidence on the 13th century, Medium Aevum Quotidianum, 68, 5-46, 2014.

Kiss, A.: Droughts and low water levels in Late Medieval Hungary II: 1361, 1439, 1443-4, 1455, 1473, 1480, 1482(?), 1502-

3, 1506: documentary versus three-ring (owda) evidence, Journal of Environmental Geography, 10, 43-56, 2017.

Kiss, A.: Before and after the Great Heat and Drought of 1540: multiannual trends of grape and grain harvest dates in the Vienna Hospital Accounts, in: Genius loci. Laszlovszky 60, Drosztmér, Á., Lyublyanovics, K., Rasson, J., Papp Reed, Z., Vadas, A., Zatykó, C. (Eds.), Budapest, 117-120, 2018.

Kiss, A.: A dynamic interplay of weather, biological factors and socio-economic interactions: Late 15th-century - early 16th century crises in Hungary, in: The Dance of Death in Late Medieval and Renaissance Europe: Environmental Stress, Mortality and Social Response, Kiss, A., Pribyl, K. (Eds.), London-New York, 125-145, 2019.

Kiss, A. and Nikolić, Z.: Droughts, Dry Spells and Low water Levels in Medieval Hungary (and Croatia) I: The Great Droughts of 1362, 1474, 1479, 1494 and 1507, Journal of Environmental Geography, 8, 11-22, 2015.

Kiss, A. and Pribyl, K. (Eds.): The Dance of Death in Late Medieval and Renaissance Europe: Environmental Stress, Mortality and Social Response, London-New York, 2019.

Krieger, M., Lohmann, G., and Laepple, T.: Seasonal climate impacts on the grape harvest date in Burgundy (France), Clim. Past, 7, 425-435, doi:10.5194/cp-7-425-2011, 2011.

Kutrzeba, S. and Duda, F.: Regestra thelonei aquatici Wladislaviensis: saeculi XVI, Księgarnia G. Gebethnera, Kraków, 1915.

Labbé, T., Pfister, C., Brönnimann, S., Rousseau, D., Franke, J., and Bois, B.: The longest homogeneous series of grape harvest dates, Beaune 1354-2018, and its significance for the understanding of past and present climate, Clim. Past, 15, 1485-1501, doi:10.5194/cp-15-1485-2019, 2019.

Legatowicz, I.: Jana Hermana z Neydenburku Ziemianin albo Gospodarz inflandski: w roku M.D.C.LXII do druku podany, a teraz z niemieckiego na polski język przetłumaczony w roku 1671 i powtórnym razem w druk podany w Słucku w drukarni roku 1673, a z tego przedrukowany znowu r. 1823, Mińsk, 1823. 
Leskiewiczowa, J.: Znaczenie inwentarzy dóbr ziemskich dla badań historii wsi w Polsce XVIII w., Kwartalnik Historyczny, 60, 363-378, 1953.

Liu, Z., Fu, B., Zheng, X., and Liu, G.: Plant biomass, soil water content and soil N:P ratio regulating soil microbial functional diversity in a temperate steppe: A regional scale study, Soil Biology and Biochemistry, 42, 445-450, doi:10.1016/j.soilbio.2009.11.027, 2010.

Ljungqvist, F. C., Seim, A., and Huhtamaa, H.: Climate and society in European history, WIREs Clim Change, 12, doi:10.1002/wcc.691, 2021.

Ludwig, K.-H.: Zur Besiedlung des Weichseldeltas durch die Mennoniten: die Siedlungen der Mennoniten im Territorium der Stadt Elbing und in der Ökonomie Marienburg bis zur Übernahme der Gebiete durch Preußen 1772, Marburg-Lahn, 1961.

Łabędzki, L. Ł. and Bąk, B.: Impact of meteorological drought on crop water deficit and crop yield reduction in Polish agriculture, Journal of Water and Land Development, 34, 181-190, doi:10.1515/jwld-2017-0052, 2017.

Maciejewska, W. (Ed.): Katalog inwentarzy dóbr ziemskich XVI-XVIII wieku sporządzony na podstawie ksiąg grodzkich i ziemskich, Warszawa, 1959.

Mahajan, G., George-Jaeggli, B., Walsh, M., and Chauhan, B. S.: Effect of Soil Moisture Regimes on Growth and Seed Production of Two Australian Biotypes of Sisymbrium thellungii O. E. Schulz, Frontiers in plant science, 9, 1241, doi:10.3389/fpls.2018.01241, 2018.

Małowist, M.: Wschód a zachód Europy w XIII-XVI wieku. Konfrontacja struktur społeczno-gospodarczych, Wydawnictwo Naukowe PWN, Warszawa, 2006.

Mauelshagen, F.: Klimageschichte der Neuzeit, Darmstadt, 2010.

Mielczarski, S.: Rynek zbożowy na ziemiach polskich w drugiej połowie XVI i pierwszej połowie XVII wieku: próba rejonizacji, Gdańsk, 1962.

Modrzyński, P. M.: Ochrona przeciwpożarowa w Toruniu w świetle ustawodawstwa wilkierzowego (XIII-XVI w.), Rocznik Toruński, 44, 7-22, 2017.

Myśliwski, G.: Wrocław w przestrzeni gospodarczej Europy (XIII-XV wiek): centrum czy peryferie?, Wrocław, 2009.

Newman, I. E. and Harvey, P. D. A.: Did Soil Fertility Decline in Medieval English Farms? Evidence from Cuxham, Oxfordshire, 1320-1340, Agricultural History Review, 45, 119-136, 1997.

Nowosad, W. and Oliński, P.: The extreme year of 1540 in terms of climate variation from the perspective of historical sources derived from the Polish and Baltic territories, in: The dance of death in Late Medieval and Renaissance Europe, environmentall stress, mortality and social response, Kiss, A., Pribyl, K. (Eds.), Routledge, London, 146-155, 2020.

Orth, R., Vogel, M. M., Luterbacher, J., Pfister, C., and Seneviratne, S. I.: Did European temperatures in 1540 exceed present-day records?, Environ. Res. Lett., 11, 114021, doi:10.1088/1748-9326/11/11/114021, 2016.

Parker, G.: Global crisis: war, climate change and catastrophe in the seventeenth century, Yale University Press, New Haven, 2013. 
https://doi.org/10.5194/cp-2021-157

Preprint. Discussion started: 29 November 2021

(c) Author(s) 2021. CC BY 4.0 License.

\section{(c) (1)}

Pelc, J.: Ceny w Krakowie w latach 1396-1600, Lwów, 1935.

Pelc, J.: Ceny w Gdańsku w XVI i XVII wieku, Warszawa, 1937.

Pfister, C.: When Europe was burning. The muti-seasonal drought of 1540 and the arsonist paranoia, in: Disasters, Risks and Cultures. A Disaster, Risks and Cultures. Comparative and Transcultural Survey of Historical Disaster Experiences between Asia and Europe, Schenk, G. J. (Ed.), Springer, Cham, 155-185, 2017.

Pfister, C.: The "Black Swan" of 1540. Aspects of a European Megadrought, in: Climatic Change and Cultural Transition in Europe, Leggewie, K., Mauelshagen, F. (Eds.), Brill, Leiden, 156-196, 2018.

Pfister, C., Wetter, O., Brázdil, R., Dobrovolný, P., Glaser, R., Luterbacher, J., Seneviratne, S. I., Zorita, E., Alcoforado, M.J., Barriendos, M., Bieber, U., Burmeister, K. H., Camenisch, C., Contino, A., Grünewald, U., Herget, J., Himmelsbach, I., Labbé, T., Limanówka, D., Litzenburger, L., Kiss, A., Kotyza, O., Nordli, Ø., Pribyl, K., Retsö, D., Riemann, D., Rohr, C., Siegfried, W., Spring, J.-L., Söderberg, J., Wagner, S., and Werner, J. P.: Tree-rings and people - different views on the 1540 Megadrought. Reply to Büntgen et al. 2015, Climatic Change, 131, 191-198, doi:10.1007/s10584015-1429-8, 2015.

Piekosiński, F.: Prawa, przywileje i statuta miasta Krakowa (1507-1795), 1, Kraków, 1885.

Piprek, J.: (M. Grossner) Krótkie wprowadzenie do gospodarstwa wiejskiego, Wrocław, 1954.

Przybylak, R., Oliński, P., Koprowski, M., Filipiak, J., Pospieszyńska, A., Chorążyczewski, W., Puchałka, R., and Dąbrowski, H. P.: Droughts in the area of Poland in recent centuries in the light of multi-proxy data, Clim. Past, 16, 627-661, doi:10.5194/cp-16-627-2020, 2020.

Rostafiński, J.: Teodora Zawadzkiego “Memoriale oeconomicum”, 1616, Kraków, 1891.

Rutkowski, J.: Skarbowość polska za Aleksandra Jagiellończyka, Kwartalnik Historyczny, 23, 1909.

Samsonowicz, H.: Handel zagraniczny Gdańska w drugiej połowie XV wieku: rejonizacja handlu na podstawie ksiąg cła palowego, Przegląd Historyczny, 47, 283-352, 1956.

Samsonowicz, H. and Bogucka, M.: Dzieje miast i mieszczaństwa w Polsce przedrozbiorowej, Wrocław, 1986.

Schofield, J. and Vince, A.: Medieval Towns. The Archaeology of British Towns in their European Setting, LondonOakville, 2005.

Seneviratne, S. I., Nicholls, N., Easterling, D., Goodess, C. M., Kanae, S., Kossin, J., Luo, Y., Marengo, J., McInnes, K., Rahimi, M., Reichstein, M., Sorteberg, A., Vera, C., and Zhang, X.: Changes in climate extremes and their impacts on the natural physical environment, in: Managing the Risks of Extreme Events and Disasters to Advance Climate Change Adaptation, Field, C. B., Barros, V., Stocker, T. F., Qin, D., Dokken, D. J., Ebi, K. L., Mastrandrea, M. D., Mach, K. J., Plattner, G.-K., Allen, S. K., Tingor, M., Midgley, P. M. (Eds.), Special Report of the Intergovernmental Panel on Climate Change (IPCC), Cambridge University Press, Cambridge, 109-230, 2012.

Senkowski, J.: Lustracja poradlnego i rejestr łanów województw brzesko-kujawskiego i inowrocławskiego z roku 1489, Teki Archiwalne, 7, 69-214, 1961.

Senkowski, J.: Skarbowość Mazowsza od końca XIV wieku do 1526 roku, Warszawa, 1965. 
https://doi.org/10.5194/cp-2021-157

Preprint. Discussion started: 29 November 2021

(c) Author(s) 2021. CC BY 4.0 License.

(c) (i)

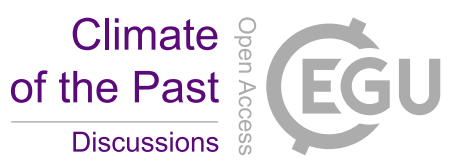

745 Siebielec, S., Siebielec, G., Klimkowicz-Pawlas, A., Gałązka, A., Grządziel, J., and Stuczyński, T.: Impact of Water Stress on Microbial Community and Activity in Sandy and Loamy Soils, Agronomy, 10, 1429, doi:10.3390/agronomy10091429, 2020.

Słoń, M. (Ed.): Historical atlas of Poland in the 2 nd half of the 16th century voivodeships of Cracow, Sandomierz, Lublin, Sieradz, Łęczyca, Rawa, Płock and Mazovia, Peter Lang, Frankfurt am Main, 2014.

Sowina, U.: Les eaux qui charrient la mort et les désastres: inondations et pollution des eaux dans les villes polonaises aux XV et XVI siècles, in: Cities and catastrophes, Platt, H. L., Schott, D. (Eds.), Peter Lang, Frankfurt am Main, 43-61, 2002.

Sułkowska, I.: Księgi polskiej kancelarii koronnej w drugiej połowie XV w., Studia Źródłoznawcze, 6, 81-101, 1961.

Sułkowska-Kurasiowa, I.: Księgi Wpisów Metryki Koronnej (1447-1794) w Archiwum Głównym Akt Dawnych w Warszawie, Archeion, 44, 1966.

Szpak, J.: Kierunki produkcji dworskiej w ekonomii malborskiej w XVI wieku, Zakład Narodowy im. Ossolińskich Wydawnictwo PAN, Wrocław, 1971.

Trawkowski, S.: W sprawie roli kolonizacji niemieckiej w przemianach kultury materialnej na ziemiach polskich w XIII w., Kwartalnik Historii Kultury Materialnej, 8, 185-205, 1960.

Wang, M., Shi, S., Lin, F., Hao, Z., Jiang, P., and Dai, G.: Effects of soil water and nitrogen on growth and photosynthetic response of Manchurian ash (Fraxinus mandshurica) seedlings in northeastern China, PloS one, 7, e30754, doi:10.1371/journal.pone.0030754, 2012.

Wawrzyńczyk, A.: Stan badań nad wysokością plonów w rolnictwie Polskim XVI-XVIII w., Kwartalnik Historii Kultury Materialnej, 8, 103-117, 1960.

Wawrzyńczyk, A.: Studia nad wydajnością produkcji rolnej dóbr kólewskich w drugiej połowie XVI wieku, WrocławWarszawa-Kraków, 1974.

Wetter, O. and Pfister, C.: An underestimated record breaking event - why summer 1540 was likely warmer than 2003, Clim. Past, 9, 41-56, doi:10.5194/cp-9-41-2013, 2013.

Wetter, O., Pfister, C., Werner, J. P., Zorita, E., Wagner, S., Seneviratne, S. I., Herget, J., Grünewald, U., Luterbacher, J., Alcoforado, M.-J., Barriendos, M., Bieber, U., Brázdil, R., Burmeister, K. H., Camenisch, C., Contino, A., Dobrovolný, P., Glaser, R., Himmelsbach, I., Kiss, A., Kotyza, O., Labbé, T., Limanówka, D., Litzenburger, L., Nordl, Ø., Pribyl, K., Retsö, D., Riemann, D., Rohr, C., Siegfried, W., Söderberg, J., and Spring, J.-L.: The year-long unprecedented European heat and drought of 1540 - a worst case, Climatic Change, 125, 349-363, doi:10.1007/s10584-014-1184-2, 2014.

Weyman, S.: Pierwsze ustawy pogłównego generalnego w Polsce na tle ówczesnego systemu podatkowego, Roczniki Dziejów Społecznych i Gospodarczych, 18, 1956.

White, S., Moreno-Chamarro, E., Zanchettin, D., Huhtamaa, H., Degroot, D., Stoffel, M., and Corona, C.: The 1600 Huaynaputina Eruption as Possible Trigger for Persistent Cooling in the North Atlantic Region, Clim. Past, doi:10.5194/cp-2021-82, 2021. 
https://doi.org/10.5194/cp-2021-157

Preprint. Discussion started: 29 November 2021

(c) Author(s) 2021. CC BY 4.0 License.

(c) (1)

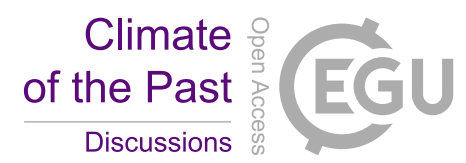

Wierzbowski, T.: Sigismundi I regis tempora complectens (1507-1548): Vol. 1, Acta cancellariorum 1507-1548, Varsoviae, 1910.

Wierzbowski, T.: Sigismundi I regis tempora complectens (1507-1548): Vol. 2, Acta vicecancellariorum 1507-1535, Varsoviae, 1912.

Wierzbowski, T.: Sigismundi I regis tempora complectens (1507-1548): Vol. 3, Acta vicecancellariorum 1533-1548, Varsoviae, 1915.

785 Wierzbowski, T.: Sigismundi I regis tempora complectens (1507-1548): Vol. 4, Indices rerum, personarum et locorum 1507 1548, Varsoviae, 1917.

Wierzbowski, T.: Sigismundi Augusti regis tempora complectens (1548-1572): Vol. 1, Acta cancellariorum 1548-1572, Varsoviae, 1919.

Wilhite, D. A. and Glantz, M. H.: Understanding: the Drought Phenomenon: The Role of Definitions, Water International, 10, 111-120, doi:10.1080/02508068508686328, 1985.

Wolański, M.: Ceny we Wrocławiu w latach 1506-1618, Wrocław, 1996.

Wyczański, A.: Z dziejów reform skarbowo-wojskowych za. Zygmunta I. Próby relucji pospolitego ruszenia, Przegląd Historyczny, 43, 287-304, 1952.

Wyczański, A.: O badaniu plonów zbóż w dawnej Polsce, Kwartalnik Historii Kultury Materialnej, 16, 251-271, 1968.

795 Wyczański, A.: La Consommation alimentaire en Pologne aux XVIe et XVIIe siècles., Publications de la Sorbonne, Paris, 1985.

Zajęcki, M.: Instrumenty prawne ochrony przeciwpożarowej w miastach Polski przedrozbiorowej, Poznań, 2014.

Związek, T.: Kształtowanie sieci młynów wodnych na przykładzie powiaty konińskiego (ok. 1300-1550), Studia Geohistorica, 2, 118-142, 2014.

800 Żaboklicka, A.: Zmiany w strukturze drobnej własności szlacheckiej w XV-XVI w. na przykładzie ziemi liwskiej, Przegląd Historyczny, 49, 250-260, 1958.

Żytkowicz, L.: Studia nad gospodarstwem wiejskim w dobrach kościelnych w XVI w., Warszawa, 1962. 
https://doi.org/10.5194/cp-2021-157

Preprint. Discussion started: 29 November 2021

(c) Author(s) 2021. CC BY 4.0 License.

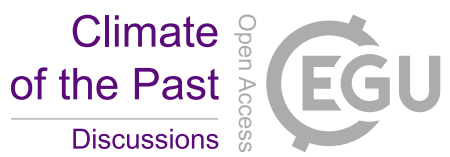

(c) (1)

\section{Figures}

FIGURE 1. Distribution of areas analyzed in the text in the spatial context of Vistula river exports in the 16th century (before the Union of Lublin of 1569).

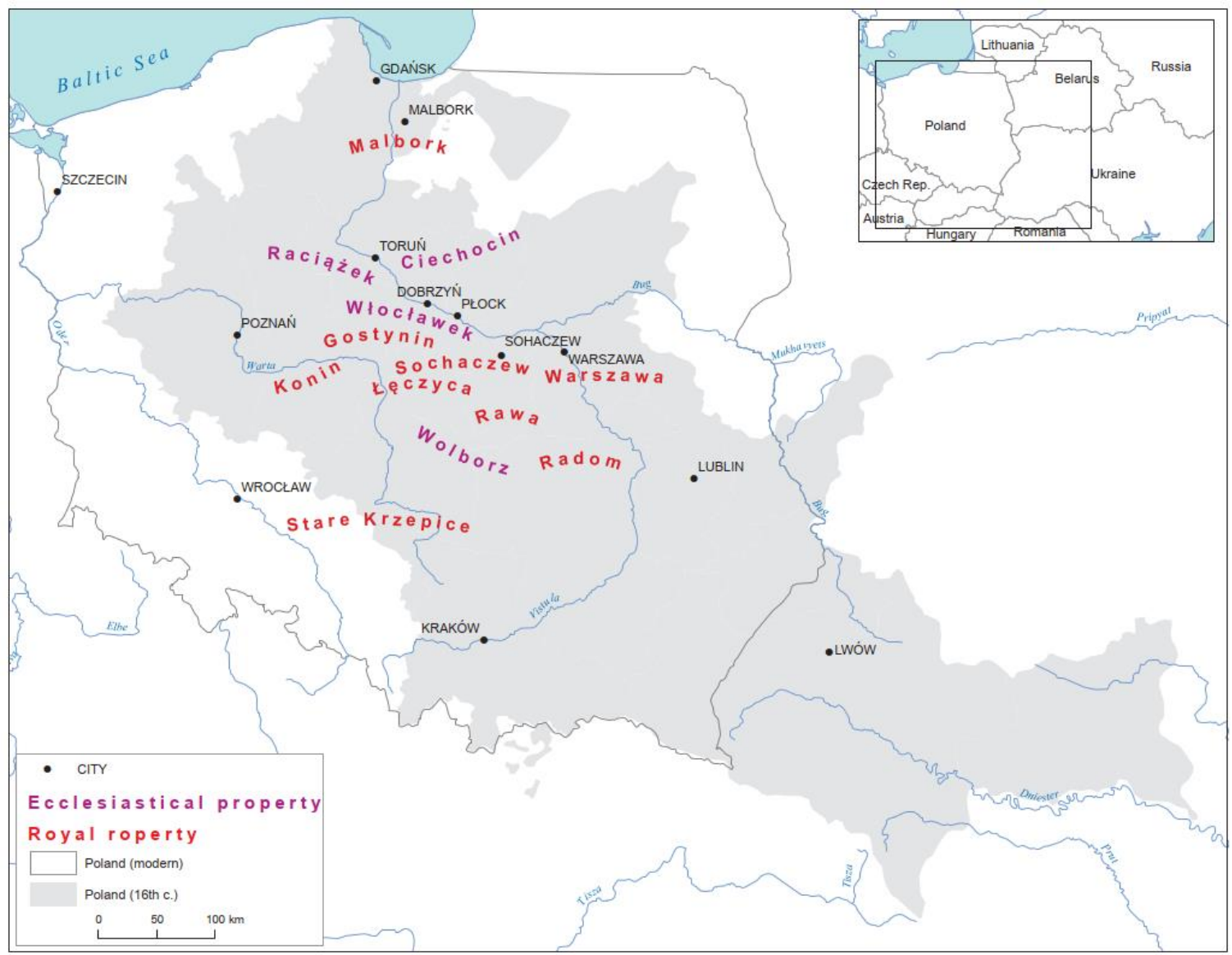


https://doi.org/10.5194/cp-2021-157

Preprint. Discussion started: 29 November 2021

(c) Author(s) 2021. CC BY 4.0 License.

(c) (i)

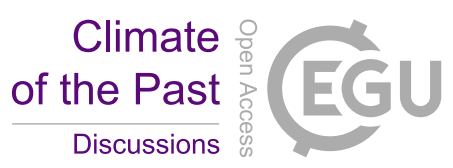

FIGURE 2. Changes in cultivated land based on surviving tax summaries from 1533, 1535 and 1543. Sources: Archival

820 Sources $1-3$.

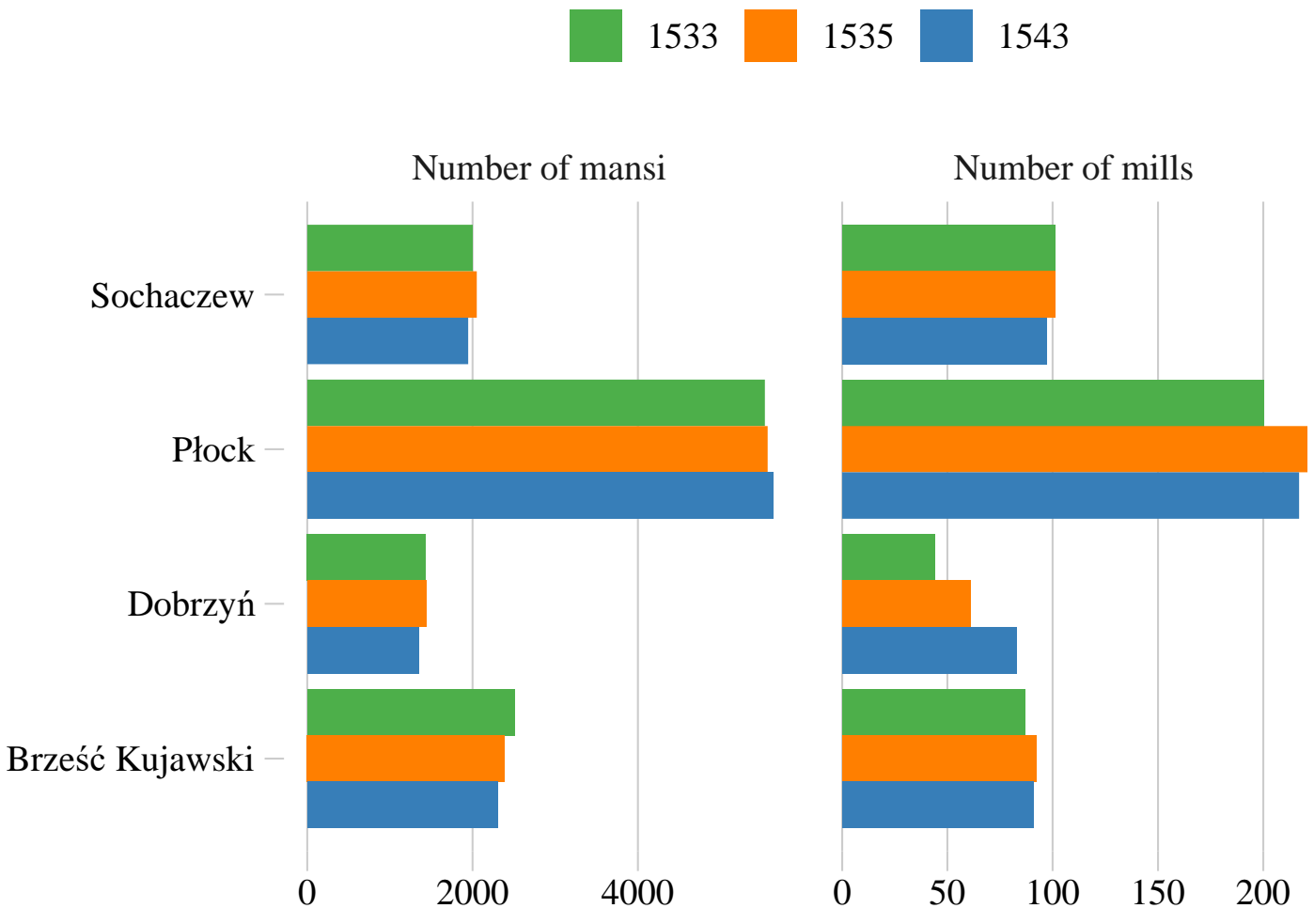


https://doi.org/10.5194/cp-2021-157

Preprint. Discussion started: 29 November 2021

(c) Author(s) 2021. CC BY 4.0 License.

\section{Climate of the Past \\ Discussions

FIGURE 3. Vistula Fens settlement

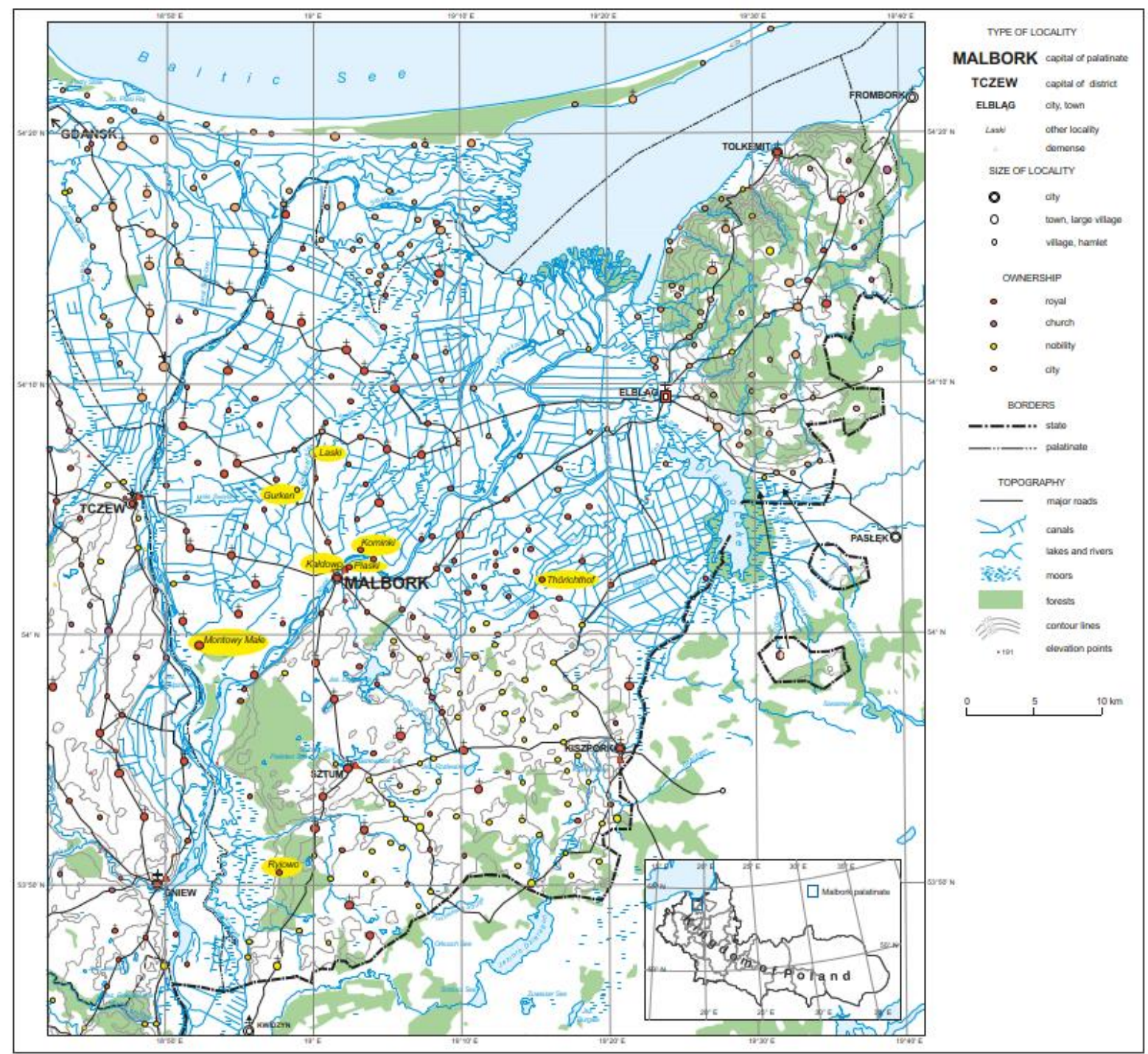


https://doi.org/10.5194/cp-2021-157

Preprint. Discussion started: 29 November 2021

(c) Author(s) 2021. CC BY 4.0 License.

Climate

Discussions

(c) (i)

FIGURE 4. Grain yield ratio of main crops in Malbork Royal Economy. Sources: (Szpak, 1971).

Bareley

10.0

$$
7.5
$$

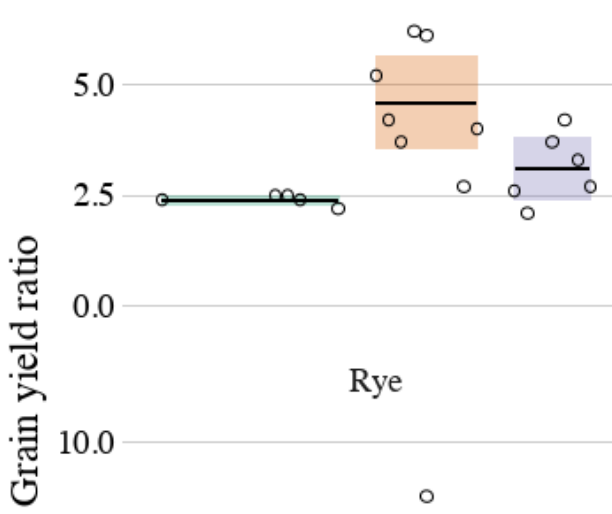

7.5

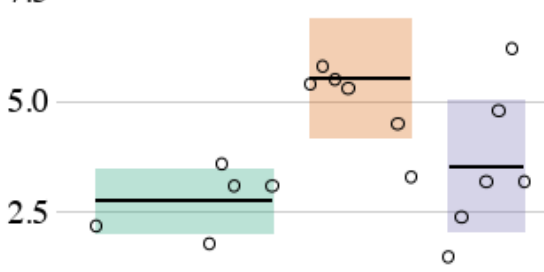

0.0
Oats

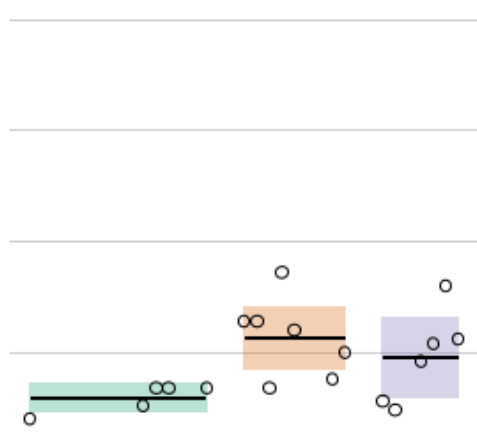

Wheat

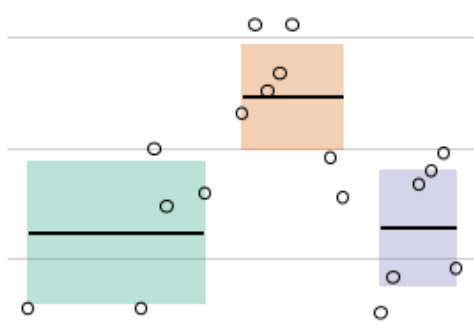

$\begin{array}{llll}1520 & 1530 & 1540 & 1550\end{array}$
Pea

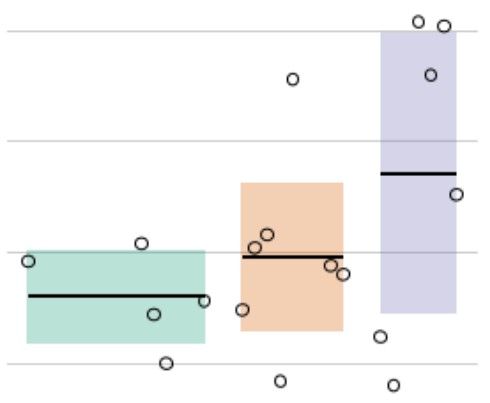

1520 
https://doi.org/10.5194/cp-2021-157

Preprint. Discussion started: 29 November 2021

(c) Author(s) 2021. CC BY 4.0 License.

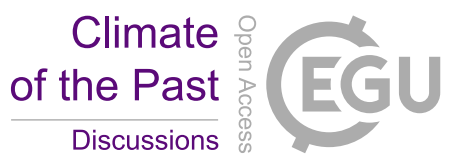

FIGURE 5. Volume of grain harvests in Malbork Royal Economy (calculated in coreti; 1 coretus $=55 \mathrm{~kg}$ ). Sources: (Szpak,

1971)

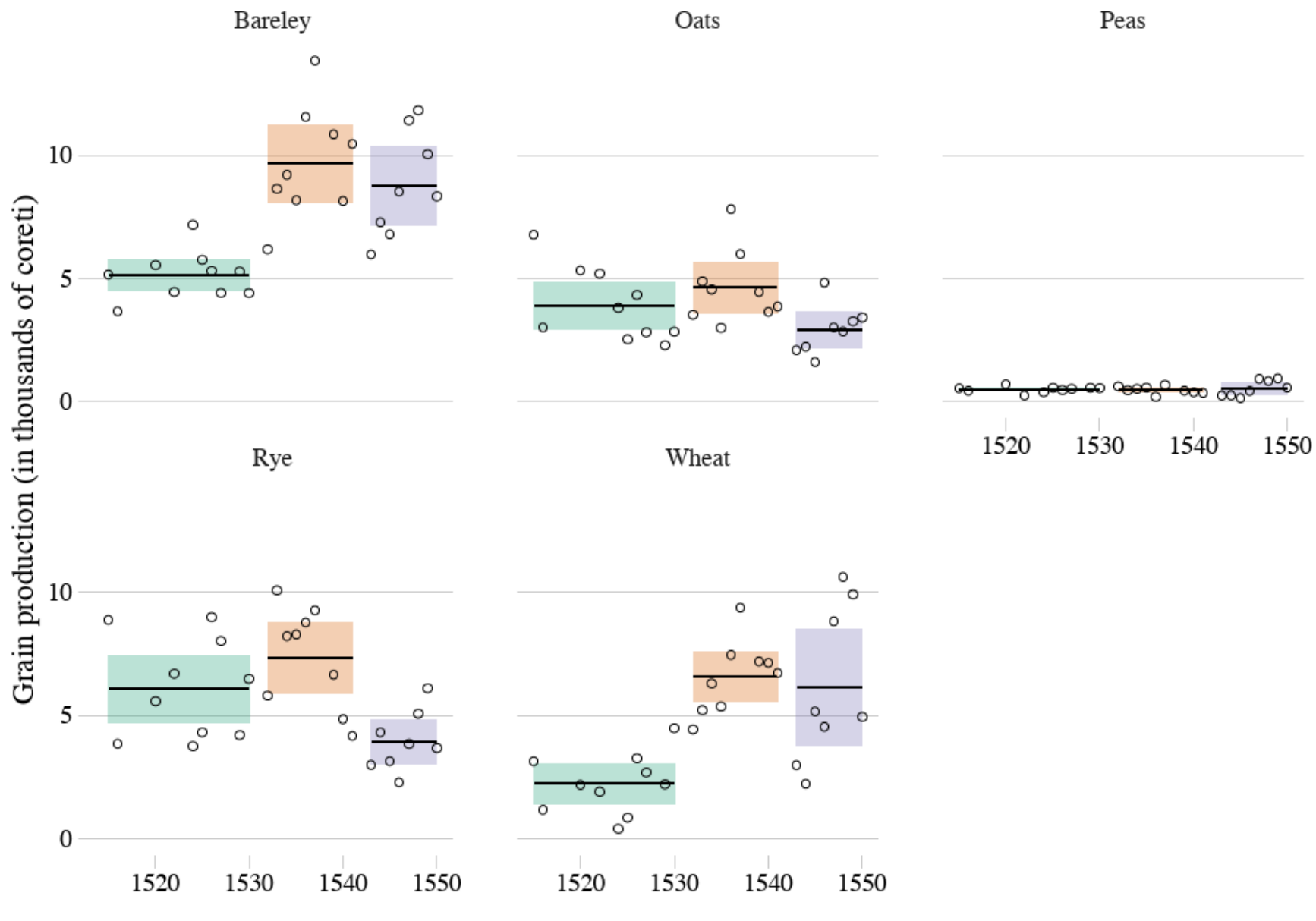


https://doi.org/10.5194/cp-2021-157

Preprint. Discussion started: 29 November 2021

(c) Author(s) 2021. CC BY 4.0 License.

Climate

(c) (1)

FIGURE 6. Grain yield ratio of main crops in the royal estates. Sources: (Wawrzyńczyk, 1974).
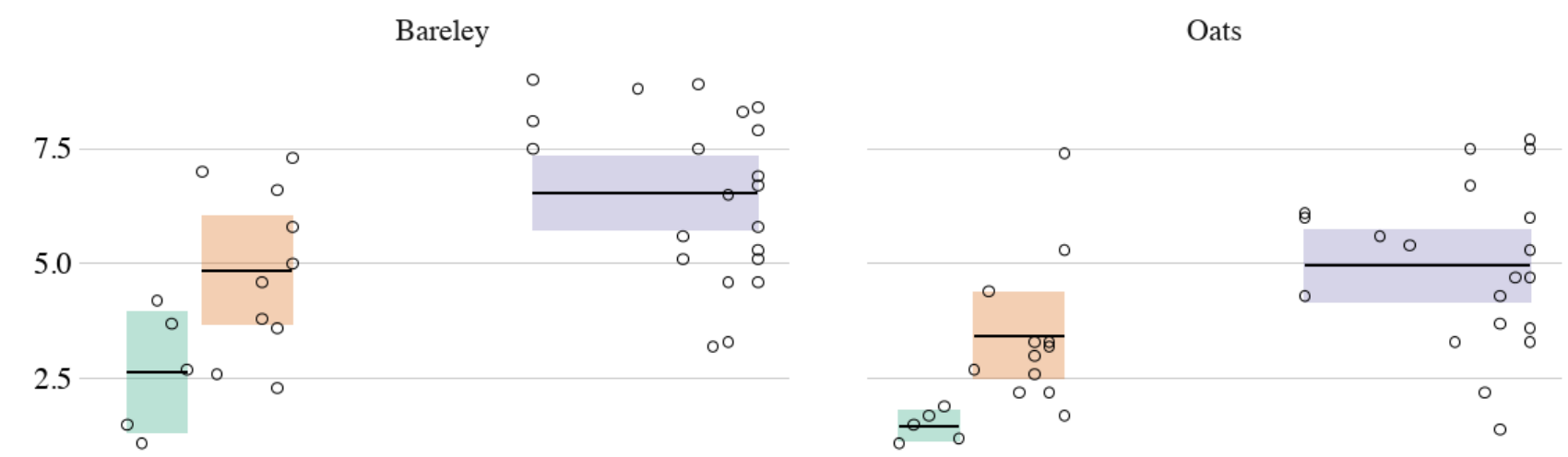

怘 0.0

Rye

Wheat
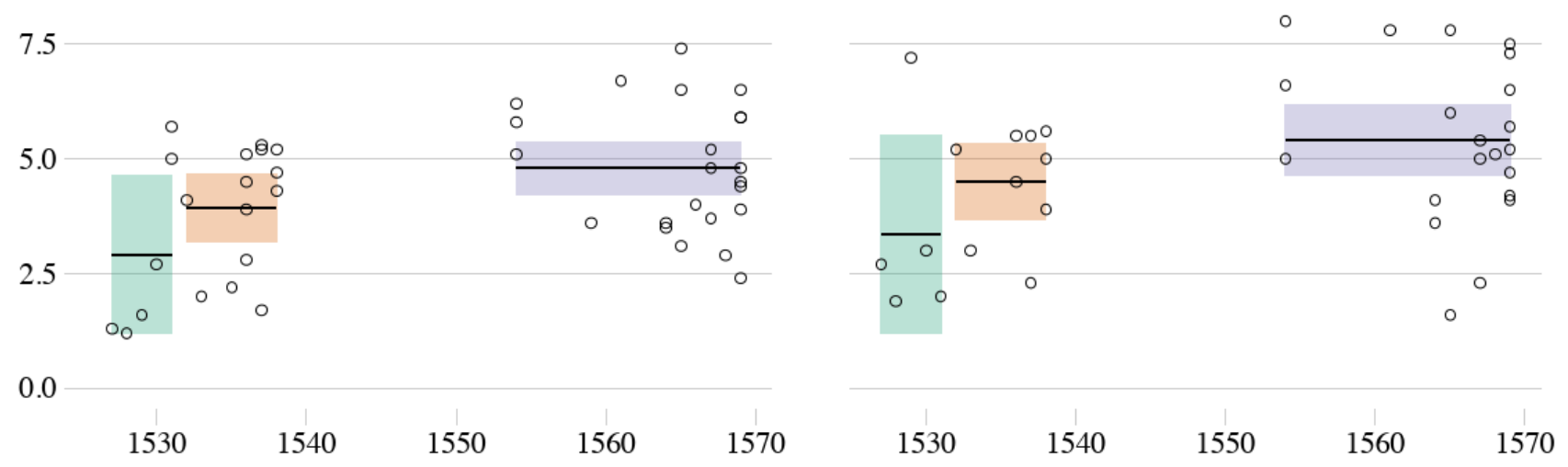
https://doi.org/10.5194/cp-2021-157

Preprint. Discussion started: 29 November 2021

(c) Author(s) 2021. CC BY 4.0 License.

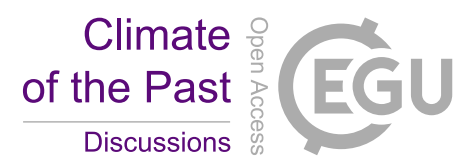

FIGURE 7. Grain yield ratio in the estates of Bishops of Włocławek. Source: (Żytkowicz, 1962).
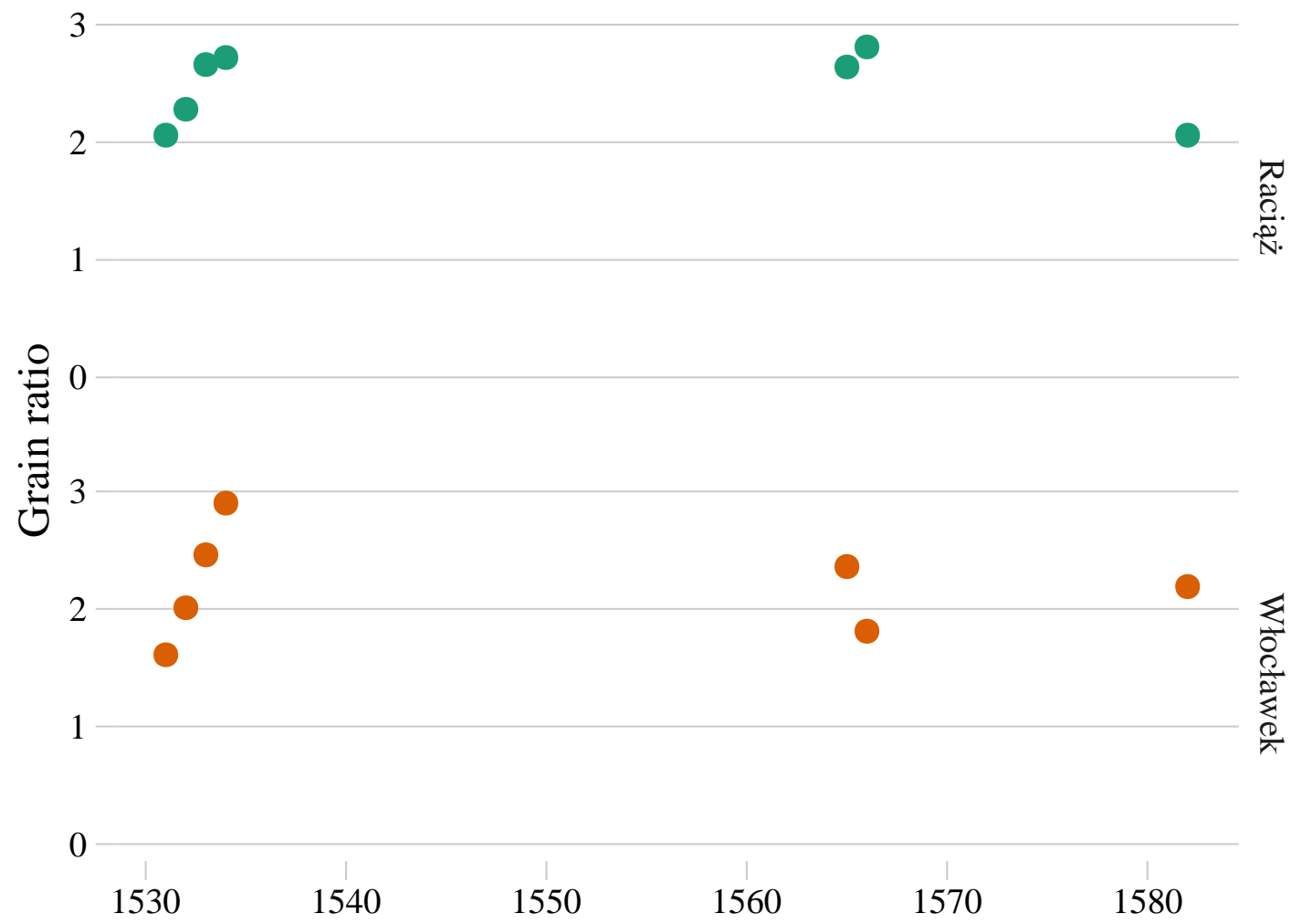
https://doi.org/10.5194/cp-2021-157

Preprint. Discussion started: 29 November 2021

(c) Author(s) 2021. CC BY 4.0 License.

FIGURE 8. Number of fires registered in Crown Metric. Source: Archival Sources 4.

$15-0$

$\circ$

$\circ$

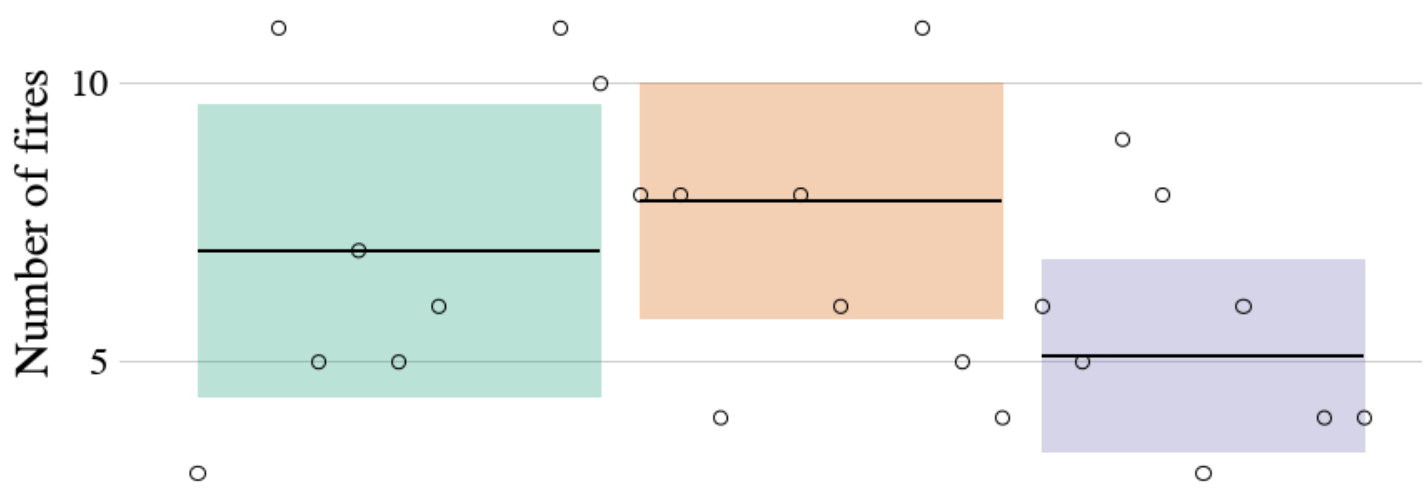

$\circ \circ$

o

0

1520

1530

1540

1550

855 
FIGURE 9. Index of fire severity categories. Source: Archival Sources 4.

\author{
Number of fires $\bigcirc 1 \bigcirc 3 \bigcirc 5 \bigcirc 7 \bigcirc 10$
}

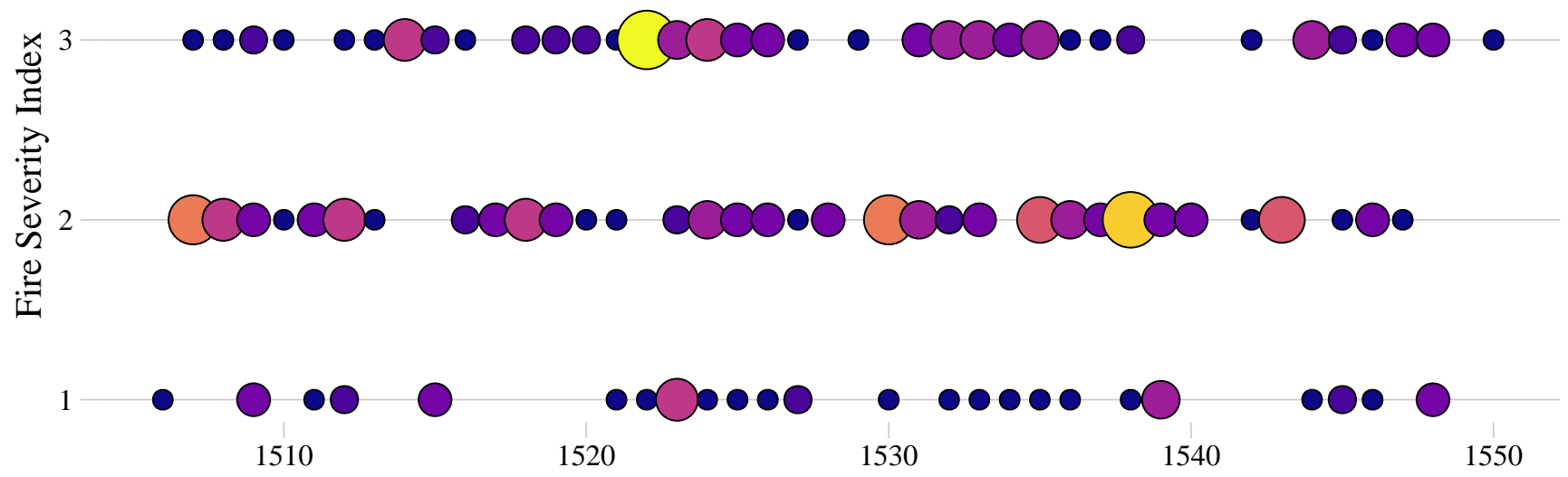


https://doi.org/10.5194/cp-2021-157

Preprint. Discussion started: 29 November 2021

(c) Author(s) 2021. CC BY 4.0 License.

(c)

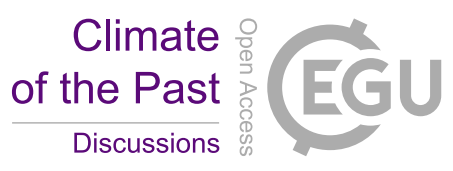

FIGURE 10. Spatial distribution of tax exemptions for cities and towns due to the fires. Source: Archival Sources 4.
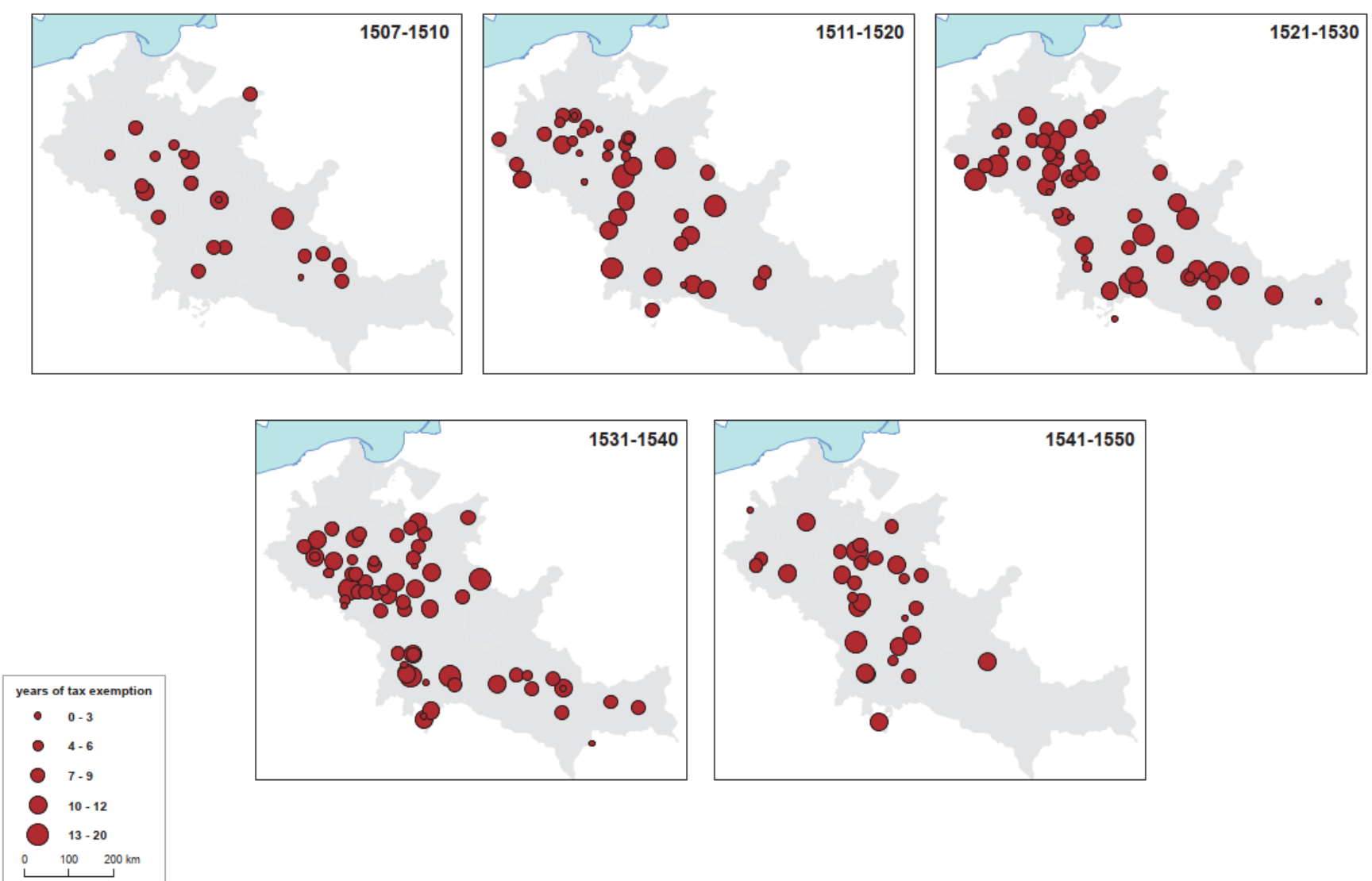
https://doi.org/10.5194/cp-2021-157

Preprint. Discussion started: 29 November 2021

(c) Author(s) 2021. CC BY 4.0 License.

(c) (1)

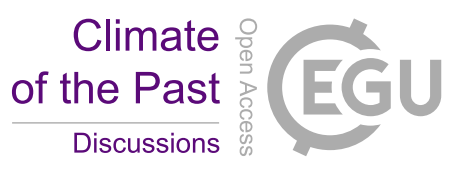

FIGURE 11. Number of fires and PDSI. Source: Archival Sources 4 and (Cook et al., 2015).

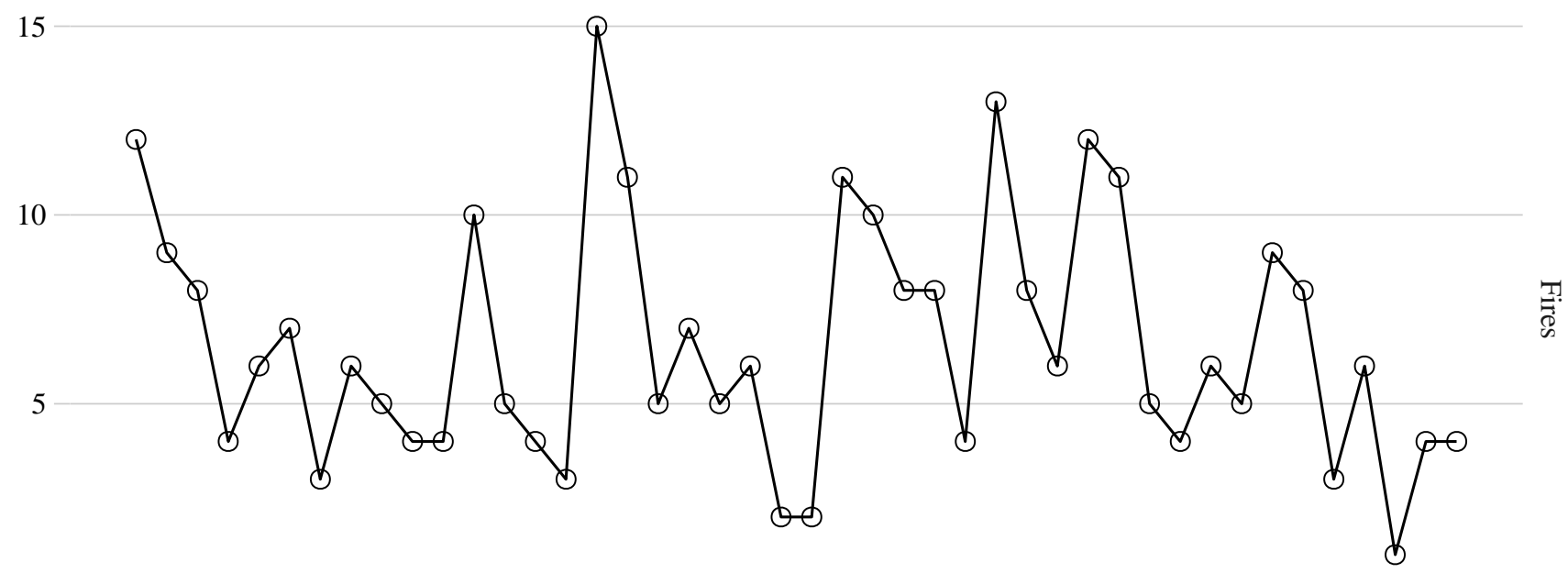

0

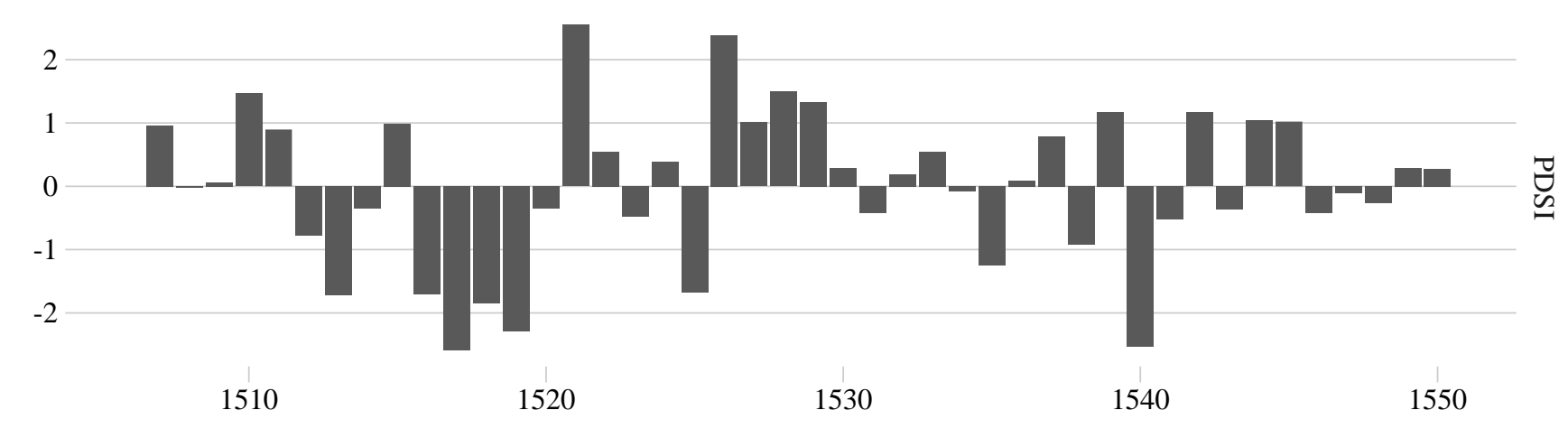

865 
FIGURE 12. Prices in Cracow, Gdańsk and Lviv. Source: (Pelc, 1935, 1937; Hoszowski, 1928).

Beer: Cracow

200

150

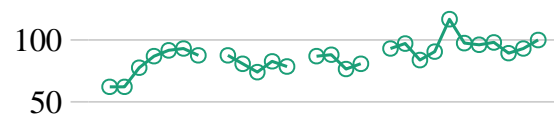

0

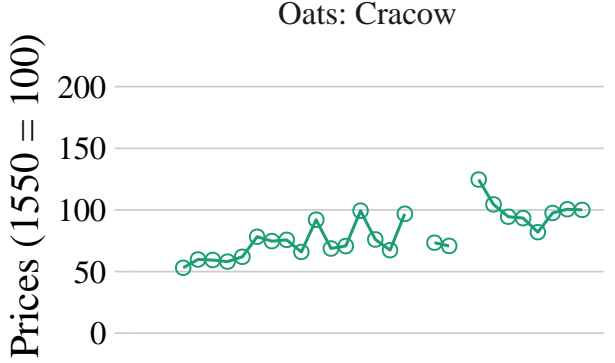

Rye: Cracow

200

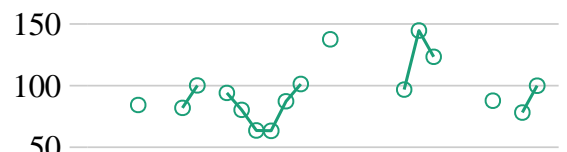

50

0

1520
Beer: Gdańsk

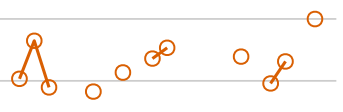

Oats: Gdańsk

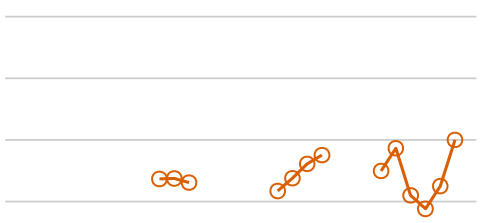

Rye: Gdańsk

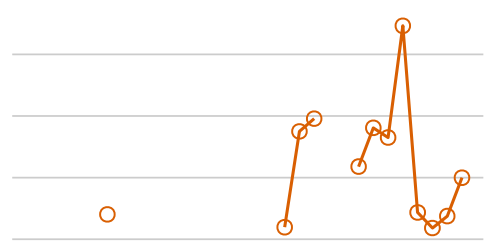

1520
Beer: Lviv

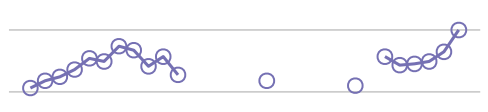

Oats: Lviv

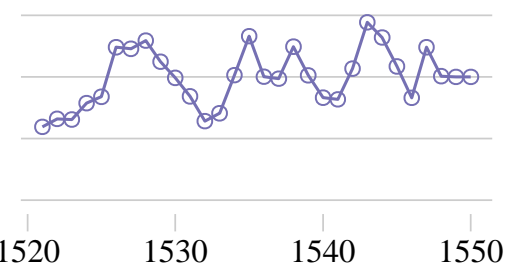

870 
https://doi.org/10.5194/cp-2021-157

Preprint. Discussion started: 29 November 2021

(c) Author(s) 2021. CC BY 4.0 License.

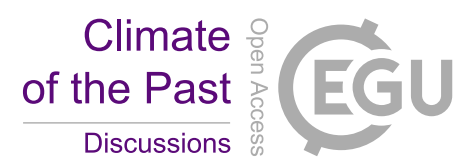

(c) (i)

FIGURE 13. Quarterly prices in Cracow. Source: (Pelc, 1935).

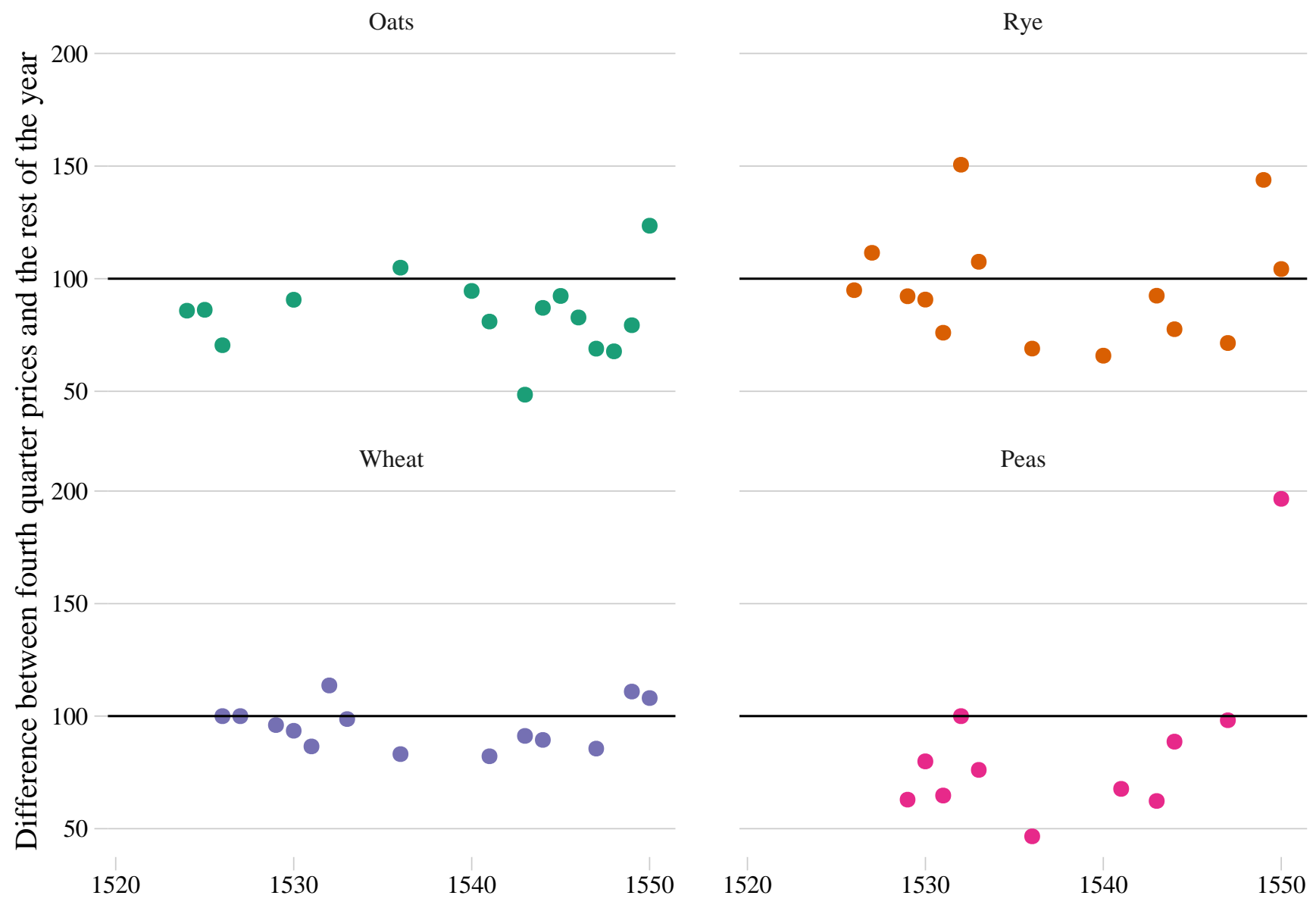


https://doi.org/10.5194/cp-2021-157

Preprint. Discussion started: 29 November 2021

(c) Author(s) 2021. CC BY 4.0 License.

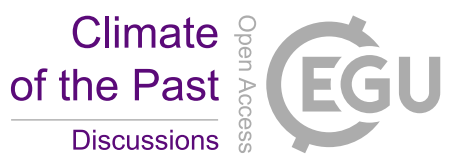

FIGURE 14. Wine prices. Source: (Pelc, 1935; Hoszowski, 1928; Wolański, 1996).
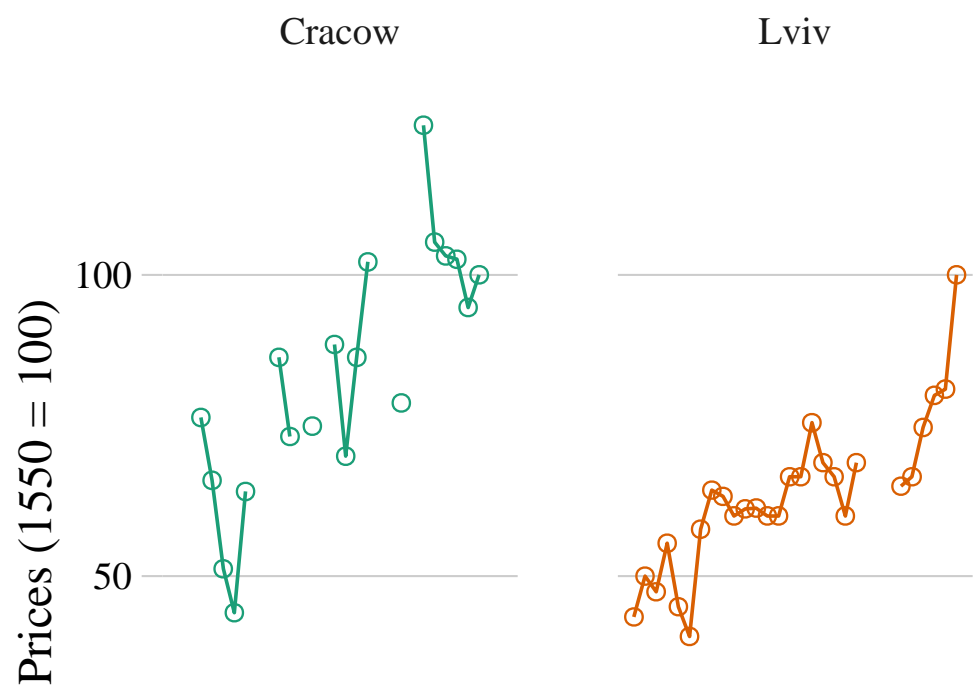

Wrocław

Lviv

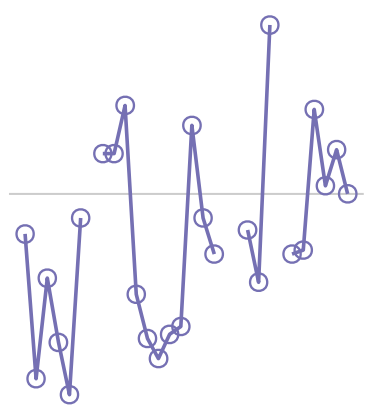

0

$\begin{array}{llllllllllll}1520 & 1530 & 1540 & 1550 & 1520 & 1530 & 1540 & 1550 & 1520 & 1530 & 1540 & 1550\end{array}$ 
FIGURE 15. Grain exports from Gdańsk. Source: (Samsonowicz, 1956; Kutrzeba and Duda, 1915).

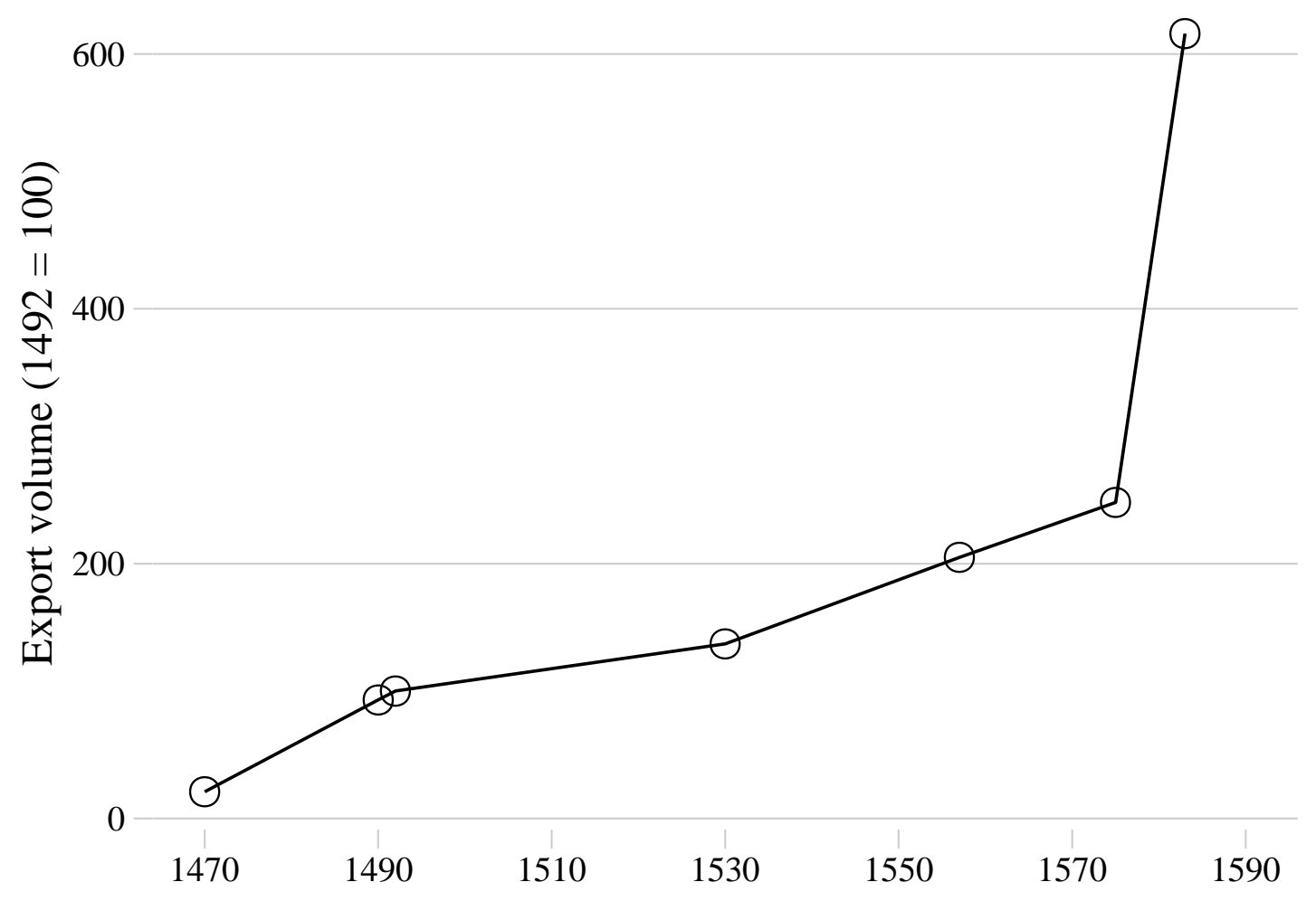


https://doi.org/10.5194/cp-2021-157

Preprint. Discussion started: 29 November 2021

(c) Author(s) 2021. CC BY 4.0 License.

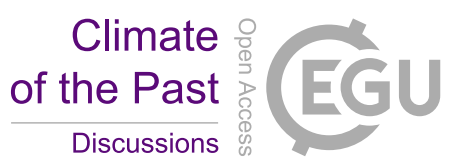

(c) (1)

FIGURE 16. Ships from Polish and Prussian ports registered in the Sundtolls. Source: (Ellinger and Korst, 1906).

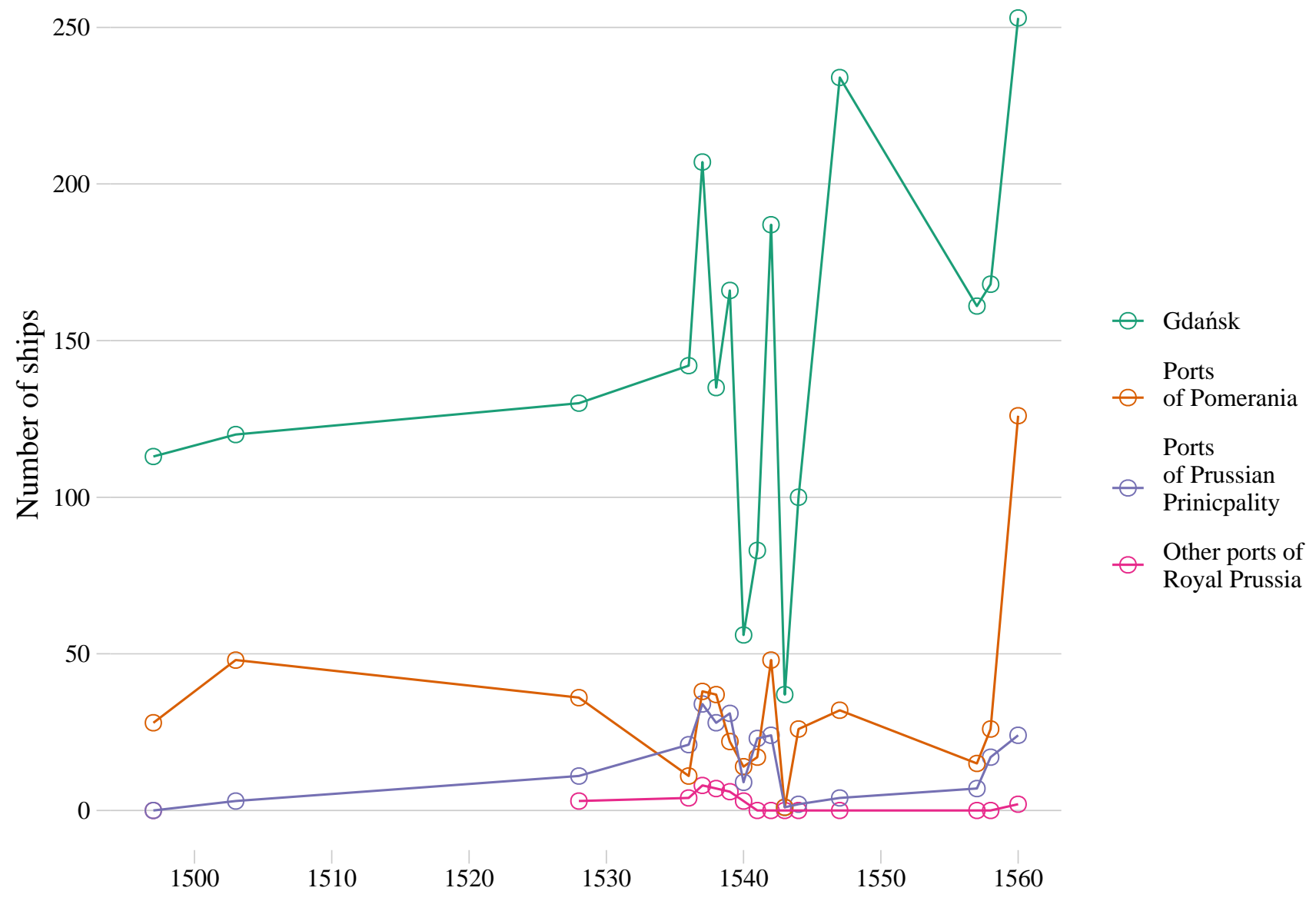


https://doi.org/10.5194/cp-2021-157

Preprint. Discussion started: 29 November 2021

(C) Author(s) 2021. CC BY 4.0 License.

(c) (i)

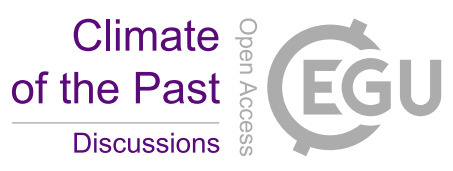

FIGURE 17. Number of ships registered in Włocławek water chamber. Source: (Kutrzeba and Duda, 1915).

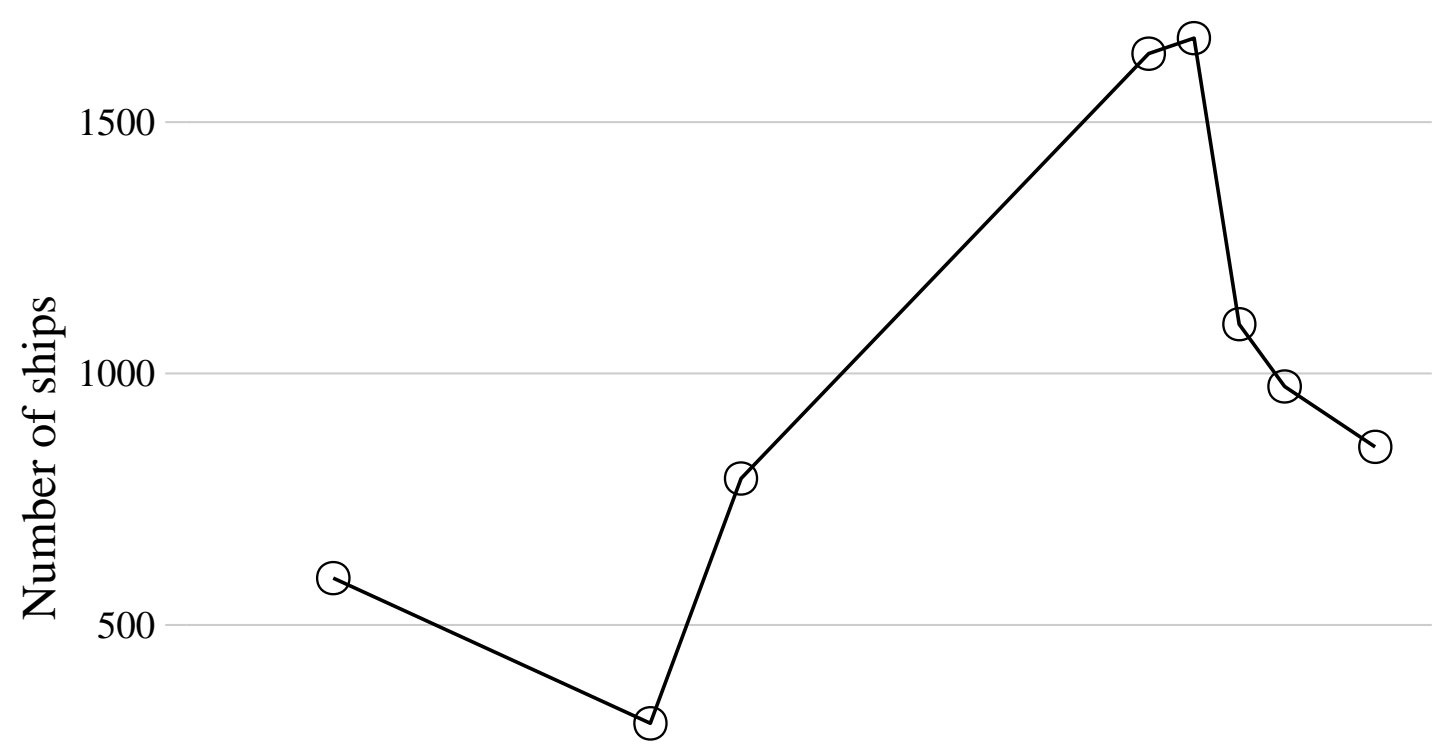

890

1535

1540

1545

1550

1555

1560 